\title{
Effects of Time-Restricted Feeding during Ramadan on Dietary Intake, Body Composition and Metabolic Outcomes
}

\author{
Farhana Osman ${ }^{1}$, Sumanto Haldar ${ }^{1}\left[\right.$ and Christiani Jeyakumar Henry ${ }^{1,2, *}$ \\ 1 Singapore Institute of Food and Biotechnology Innovations, 14 Medical Drive, Singapore 117599, Singapore; \\ farhana_osman@sifbi.a-star.edu.sg (F.O.); sumanto_haldar@sifbi.a-star.edu.sg (S.H.) \\ 2 Department of Biochemistry, National University of Singapore, 8 Medical Drive, Singapore 117596, Singapore \\ * Correspondence: jeya_henry@sifbi.a-star.edu.sg; Tel.: +65-6407-0793
}

Received: 31 July 2020; Accepted: 14 August 2020; Published: 17 August 2020

\begin{abstract}
Ramadan fasting is a form of time-restricted feeding which combines a fast and feast period daily for a duration of one month every year. During Ramadan, Muslims abstain from food and drink consumption from dawn till sunset and this change in the meal schedule and frequency results in significant changes to the composition of the diet, such as energy and nutrient intake. These changes in dietary habits and their corresponding effects on cardiometabolic disease risk are compiled in this review. Ramadan fasting shows limited benefits to body composition via reductions in body mass in both healthy and obese individuals, although the results are often found to be transient and heterogeneous. There is, however, a more consistent improvement in blood lipid profile during Ramadan fasting, which often lasts beyond the Ramadan period. The results for glucose homeostasis, on the contrary, are more conflicting and inconclusive. The heterogeneity in the findings from the various studies can be generally attributed to cultural variations in dietary habits, differences in the duration of fasting due to seasonal/climatic differences at various geographical locations, age, gender and socioeconomic status, as well as other health and lifestyle factors of the various study populations.
\end{abstract}

Keywords: Ramadan fasting; dietary intake; health outcomes; body composition; glucose homeostasis; lipid profile

\section{Introduction}

Ramadan is the holiest month for Muslims all around the world, whereby the following of its practices is obligatory for all healthy Muslims. Fasting during the month of Ramadan is one of the five essential pillars of Islam, and this practice is considered an integral part of the faith. Globally, over one billion Muslims fast during the month of Ramadan [1], and the total time of fasting ranges from less than $12 \mathrm{~h}$ to as much as $19 \mathrm{~h}$ each day [2]. Fasting during the month of Ramadan originated in the seventh century to commemorate the month that Prophet Mohammed received divine revelation [3] and its purpose is to attain spiritual growth, better self-control and learn kindness [4].

Ramadan fasting is a form of "time-restricted feeding", which combines fast and feast periods daily for a duration of one month every year. Ramadan fasting constitutes abstaining from food and drink consumption from dawn till sunset, which is typically followed by a feast. In addition to changes in the timing of food and fluid intake, Ramadan fasting results in significant changes to both energy balance and the composition of the diet [5]. The study of such changes to dietary habits and the effect of these alterations on human physiology is thus of importance.

Due to the unique nature of Ramadan fasting, although there has been extensive research done about it, the effects on human health are often contradictory, as Ramadan fasting is practised in different 
ways in different populations [5]. There are also differences in the physical activity levels of the various study populations and in the climate of the various countries, as well in the design of the various studies [5]. Therefore, it is important to investigate how the dietary habits of different populations during Ramadan impact various aspects of health.

In recent years, there has been a resurgence of interest in time-restricted feeding in relation to weight management, metabolic health and chronic disease risk [6-9]. The Ramadan fasting period offers a unique form of time-restricted feeding. Given the numerous metabolic and biological changes that occur during the Ramadan fasting period, it was deemed necessary to undertake a review to provide a source of information to those participating in the Ramadan fasting period. Inevitably, this meant the review focuses on the most relevant changes that occur during this period, notably changes in dietary habits, body composition and metabolic parameters.

In fact, there has been a lack of comprehensive reviews linking dietary changes to health outcomes during the Ramadan period. Therefore, the objective of the review was to compile various research done on these outcomes during Ramadan fasting. In particular, this paper aimed to focus on the effects of Ramadan fasting on the changes in fluid intake, dietary pattern, energy and macronutrient intakes, as well as changes in body composition, glucose homeostasis and lipid profile.

\section{Materials and Methods}

A systematic review of the published literature was conducted according to PRISMA (Preferred Reporting Items for Systematic reviews and Meta-Analyses) guidelines in two databases: PubMed and Google Scholar. The search terms used were "Ramadan fasting" AND "fluid intake", "hydration status", "dietary habits", "nutrient intake", "energy intake", "body composition", "body mass", "weight", "body fat percentage", "obesity", "glucose homeostasis" and "lipid profile", respectively. The studies were first screened by title and abstract. Those that were relevant were then further screened by full text according to the inclusion and exclusion criteria.

Only peer-reviewed research published in scientific journals measuring the effect of Ramadan fasting on selected parameters, such as dietary habits, body composition and metabolic parameters, were included in this study. Publications with data from healthy individuals were included, as well as those investigating glucose homeostasis and fluid intake in individuals with type 2 diabetes or metabolic syndrome. Studies involving surgery, all other illnesses or illnesses measuring other parameters were excluded. Publications with obese individuals were analysed and discussed separately. Any available data on physical activity were extracted for analysis but studies involving only a sub-group of athletes were excluded.

Original research papers with studies containing fewer than nine volunteers were excluded from this systematic review, as well as those involving medications. We excluded studies involving volunteers who were children, pregnant or breastfeeding. Studies were also excluded when the full text of the publication had no English translation or if there was no full text available. The flow-diagram showing study selection process is shown in Figure 1. Meta-analyses or previously published systematic reviews were discussed under relevant sections to contextualise the findings from original papers. 


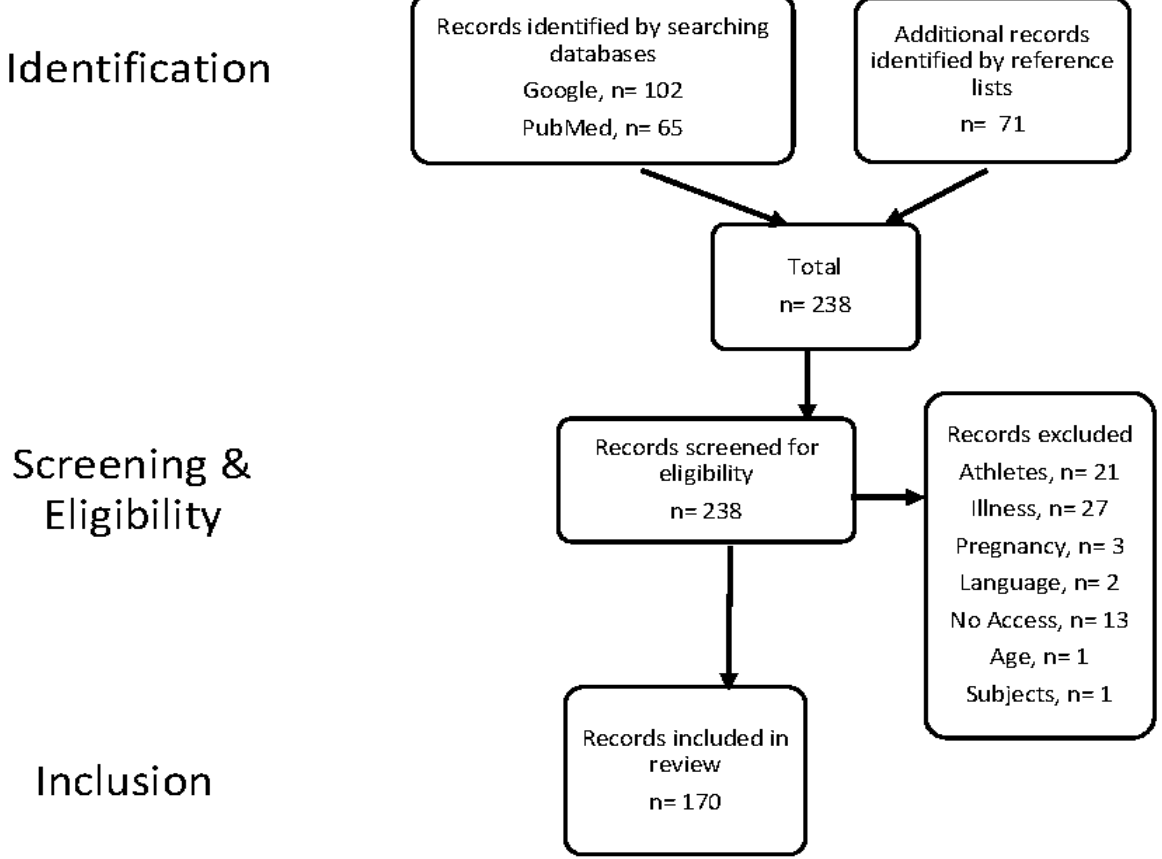

Figure 1. Flow diagram showing study selection based on inclusion and exclusion criteria.

\section{Changes in Dietary Intake}

\subsection{Fluid Intake}

It is widely believed that we need to consume approximately seven to ten glasses of water per day. Given that water intake is highly restricted within the period of Ramadan, in the first phase of this review, we will focus on the impact of fluid restriction on the levels of dehydration. Studies indicate that Ramadan fasting results in lower water intake during the month $[10,11]$. This potentially causes an alteration in kidney function, whereby water is reabsorbed by the body instead of being excreted in order to maintain fluid balance [11]. As such, there is effective water conservation during Ramadan fasting, by maximising urinary concentration as well as decreasing obligatory urine output $[1,12]$. However, prolonged dehydration induces a degree of stress on the concentrating ability of the kidneys and affects the efficiency of the water conserving mechanism [13]. The resulting hydration status of those who fast is still unclear, as there are conflicting findings regarding their level of dehydration.

Hydration status is commonly measured by serum osmolality and urine specific gravity [11]. In a study by Ibrahim et al. of 18 healthy young men during Ramadan fasting, it was found that serum osmolality levels were within the normal range, as the homeostatic mechanisms kept serum osmolality at normal levels [11]. Hosseini et al., Mustafa et al. and Dikme and Fasting also showed that there was no significant difference in serum osmolality before and during Ramadan fasting [12,14,15]. Trabelsi et al. investigated the effect of Ramadan fasting on body water levels and showed that there was no difference in total body water before and after Ramadan [16].

However, Meo and Hassan found haematocrit, plasma osmolarity and haemoglobin to be increased during Ramadan fasting and thereby possibly indicating dehydration [1]. This is in addition to an increase in urine osmolality reported in type 2 diabetics who fasted during Ramadan [17]. Furthermore, a comparison of urine specific gravity before and during Ramadan fasting by Ibrahim et al. showed that there indeed was dehydration during Ramadan fasting [11]. This state of dehydration is often caused by the fact that individuals have the same water intake habits before and during Ramadan fasting, thereby not drinking more water during non-fasting hours and eventually having lower fluid intake $[11,18]$. 
A study investigating the effect of Ramadan fasting on serum osmolarity in females showed that there was no significant change in osmolarity levels and total water when the subjects exercised regularly during Ramadan fasting, but there was a decrease in some electrolytes [14]. In a study by Ramadan et al., it was found that there was a significant increase in plasma osmolarity in those who were sedentary compared to active individuals after a month of Ramadan fasting [19].

These studies reveal that the hydration status of those who fast is dependent on their water intake habits and physical activity status. Serum osmolality levels are likely to remain in the normal range during the month of Ramadan, with increased water intake during non-fasting hours and regular exercise. Nonetheless, while Ramadan fasting has been shown to result in inadequate fluid intake in some studies, it is not clear whether it causes acute dehydration or chronic hypohydration due to the abovementioned factors that play a role in determining the hydration status of those who fast [13]. Moreover, negative water balance that may be caused by Ramadan fasting does not seem to have any detrimental health effects in the long term [12,13].

Finally, in terms of renal function parameters, studies investigating the effect of Ramadan fasting show that there was a significant reduction in serum creatinine, estimated glomerular filtration rate (eGFR) and urinary albumin/creatinine ratio in healthy individuals, but the decline was within the normal range [20]. In Muslim patients with type 2 diabetes, there was also a significant decrease in eGFR after Ramadan fasting [21]. In patients with chronic kidney disease (CKD), one study showed that there was an increase in serum creatinine in those who fasted [22], while no significant change was observed in another study [23]. Conversely, it was shown that serum creatinine significantly decreased and eGFR significantly increased in those who fasted with CKD [24]. Once again, the data show inconsistencies and the findings are generally dependent on the hydration levels during non-fasting hours, as well as other lifestyle factors during the fasting and non-fasting periods.

\subsection{Food Intake Pattern}

During Ramadan fasting, there is a variation in the frequency, timing and composition of the meals eaten [1]. However, a common pattern during fasting is one meal taken before dawn ("Suhoor") and the fast is broken by a second meal at sunset ("Iftar"), which is typically a larger meal [25]. As the number of meals consumed is reduced from three or more to two meals daily, the overall amount and types of each meal eaten are changed. This in turn also affect energy and nutrient intake [25]. Due to the latitude and longitude variations between the various nations where the primary data were obtained, the duration of fasting between sunrise and sunset varies. It is therefore a difficult challenge to integrate food intake pattern and nutrient intake to generate comparable results. Some typical examples of pre-dawn "Suhoor" and post-dusk "Iftar" meals are shown in Table $1[26,27]$ which reveals a diverse food intake pattern based on geographical location and culture.

The change in the composition of meals eaten during Ramadan is expected to contain more carbohydrate-rich foods in the form of fruits, juices and dates [1]. In a study of 366 Ghanaian adolescents, it was found that the consumption of milk and vitamin A-rich fruits increased during Ramadan, while there was a lower consumption of nuts, dark leafy vegetables and legumes [28]. On the other hand, in a study of 160 Iranian subjects, it was found that there was a higher consumption of fruits and vegetables during Ramadan, whereas the consumption of meat, dairy products and cereals decreased significantly [29]. Thus, there is a large variability between cultures and various geographical locations in the changes in dietary patterns that occur during Ramadan. 
Table 1. Food intake pattern during Ramadan in different countries around the world [26,27].

\begin{tabular}{|c|c|c|c|c|c|}
\hline & \multirow{2}{*}{ Pre-Dawn Meal (Suhoor) } & \multicolumn{4}{|c|}{ Breaking Fast Meal (Iftar) } \\
\hline & & Starters & Main & Others & Drinks \\
\hline Algeria & $\begin{array}{l}\text { - Couscous mixed with } \\
\text { sultanas and buttermilk }\end{array}$ & $\begin{array}{l}\text { Chorba soup: tomatoes, } \\
\text { vegetables, vermicelli and } \\
\text { lamb neck } \\
\text { - Borek: fried filo pastries } \\
\text { with spinach and } \\
\text { cheese/lamb and potato }\end{array}$ & $\begin{array}{ll}- & \text { Salads } \\
- & \text { Stews } \\
- & \text { Bread }\end{array}$ & $\begin{array}{l}\text { Laham lalou: dried } \\
\text { fruits cooked with } \\
\text { fresh apple/pear } \\
\text { and spices }\end{array}$ & \\
\hline Bangladesh & $\begin{array}{ll}\text { - } & \text { Chapatti } \\
\text { - } & \text { Lentil soup }\end{array}$ & $\begin{array}{l}\text { Seasonal fruits: } \\
\text { watermelon, mango, } \\
\text { guava, jackfruit }\end{array}$ & $\begin{array}{ll}- & \text { Rice } \\
- & \text { Meat/fish } \\
- & \text { Lentils } \\
- & \text { Potato cakes } \\
- & \text { Kichiri: rice, lentils, onions, } \\
& \text { garlic, ginger }\end{array}$ & & - $\quad$ Lassi \\
\hline Egypt & 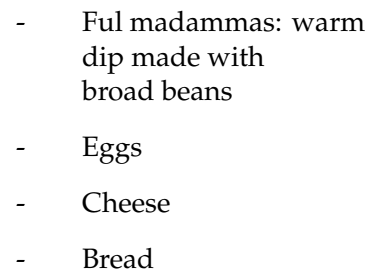 & $\begin{array}{ll}\text { - } & \text { Dates } \\
\text { - } & \text { Green salad } \\
\text { - } & \text { Dips }\end{array}$ & $\begin{array}{ll}\text { - } & \text { Sambusak: pastries with cheese } \\
\text { or meat filling } \\
\text { - } & \text { Mahshi: stuffed vegetables } \\
\text { - } & \text { Moloukhia: green } \\
& \text { leafy vegetable } \\
\text { - } & \text { Kebabs } \\
\text { - } & \text { Rice }\end{array}$ & & Milk \\
\hline Saudi Arabia & $\begin{array}{ll}- & \text { Rice } \\
\text { - } & \text { Salad } \\
\text { - } & \text { Cooked vegetables } \\
\text { - } & \text { Meat }\end{array}$ & $\begin{array}{ll}\text { - } & \text { Dates } \\
\text { - } & \text { Meat soup } \\
\text { - } & \text { Sambosa: pastry filled } \\
& \text { with meat or cheese } \\
\text { - } & \text { Pastries }\end{array}$ & $\begin{array}{ll}- & \text { Salad } \\
- & \text { Bread } \\
- & \text { Meat } \\
- & \text { Beans }\end{array}$ & Sweets & Coffee \\
\hline Singapore & - $\quad$ Bread/Cereal & $\begin{array}{ll}\text { - } & \text { Dates } \\
\text { - } & \text { Curry puff: fried pastries } \\
\text { filled with potato/sardine } \\
\text { - } \quad \text { Traditional sweet snacks }\end{array}$ & $\begin{array}{ll}- & \text { Rice } \\
\text { - } & \text { Curry } \\
\text { - } & \text { Vegetables } \\
\text { - } \quad & \begin{array}{l}\text { Rice porridge made with rice, } \\
\text { meat, vegetables and spices. }\end{array}\end{array}$ & Fruits & $\begin{array}{ll}\text { - } & \text { Bandung: } \\
& \text { sweet drink }\end{array}$ \\
\hline
\end{tabular}




\subsection{Macronutrient and Energy Intake}

Ramadan fasting has a unique effect on dietary habits, whereby changes in the composition of the meals eaten directly affect nutrient and energy intake for a period of a month. With diabetes and cardiovascular diseases being widely prevalent in Muslim communities, it is important to elucidate the extent of the effect Ramadan fasting has on nutrient and energy intake and the metabolic consequences of such changes.

When comparing nutrient intake, some studies have found an increased intake of fat during Ramadan fasting [30-37]. In a cross-sectional study involving 173 Saudi families that reported weight gain during Ramadan, it was found that $40 \%$ of the subjects attributed their weight gain to the increased consumption of foods rich in fats and carbohydrates [27]. However, other studies suggest that there is a decrease in fat intake during Ramadan fasting [38,39]. These equivocal results on fat intake must interpreted with caution. As such, these differences may be of marginal longer-term metabolic relevance. Furthermore, Savas et al. found that there was no change in the eating behaviours of obese women during Ramadan fasting [40] whereas Khaled et al. showed that, although meal frequency was decreased, there was an increase in the consumption fat and dietary cholesterol by obese subjects during Ramadan fasting [41]. The effects of Ramadan fasting on nutrient intake are listed in Table 2.

The observed differences in nutrient intake suggest that meal compositions are different across countries and cultures. This was also noted by Karaagaoglu and Yucecan, who found that, while the pre-dawn meals consisted of food that was usually eaten at breakfast, the meals at the breaking of fast seemed to be much more variable [42].

Table 2. Effect of Ramadan fasting on energy, carbohydrate, protein and fat intakes.

\begin{tabular}{|c|c|c|c|c|}
\hline Authors & Date & Country & Subjects (n) & Effect of Ramadan on Nutrient Intake \\
\hline Rahman et al. [30] & 2004 & Bangladesh & 20 males & $\begin{array}{l}\text { No change in energy, carbohydrate or protein } \\
\text { Increase in fat }\end{array}$ \\
\hline El Ati et al. [31] & 1995 & Tunisia & 16 females & Increase in protein and fat \\
\hline Frost and Pirani [33] & 1987 & Saudi Arabia & 15 & Increase in carbohydrate, protein and fat \\
\hline Yeoh et al. [34] & 2015 & Singapore & 29 & $\begin{array}{l}\text { No change in energy, carbohydrate or protein } \\
\text { Increase in fat }\end{array}$ \\
\hline Lamine et al. [35] & 2006 & Tunisia & 30 & Increase in fat \\
\hline Sadiya et al. [36] & 2011 & UAE & 19 & Decrease in protein, increase in fat \\
\hline Bouhlel et al. [37] & 2006 & Tunisia & 9 & $\begin{array}{l}\text { Decrease in carbohydrate and protein } \\
\text { Increase in fat }\end{array}$ \\
\hline Poh et al. [38] & 1996 & Malaysia & 117 & $\begin{array}{l}\text { No change in protein. Decrease in carbohydrate } \\
\text { and fat }\end{array}$ \\
\hline Suriani et al. [39] & 2015 & Malaysia & 84 & Decrease in carbohydrate \\
\hline Khattak et al. [43] & 2013 & Malaysia & 30 & No change in energy or macronutrient intake \\
\hline
\end{tabular}

Calorie intake is also affected by modifications in the timing and composition of food eaten, with a general trend in the first week of Ramadan towards a reduction in calorie intake, followed by a progressive increase through over consumption [1]. However, a study by Al-Hourani and Atoum on 57 female subjects found that the average energy and nutrient intakes before and during Ramadan were not significantly different [25], with this result being consistent with many other studies [30,31,43] and contrary to the idea that those who fast tend to consume more food than usual when breaking fast [25]. Indeed, some studies did show increases in total energy intake during Ramadan including in Saudi, Moroccan, Iranian and Turkish subjects [33,35,44-48], whereas other studies found a significant decrease in energy intake $[32,38,49,50]$. These contradictory results can again be attributed to the unique food habits of the different countries and cultures [25].

\section{Changes in Body Composition}

Since the food intake pattern is significantly altered, whereby food intake is restricted for about twelve hours, the fundamental question is whether this time-restricted feeding affects body composition 
and metabolic outcomes. In this subsequent section, we will discuss differences in body composition during Ramadan fasting compared with other times.

Studies investigating the effect of Ramadan fasting on body mass and body fat percentage show heterogeneous results, with some indicating decreases in body mass and body fat percentage [18,51-57], whereas others show no changes in body composition [31,58-61]. The heterogeneity of the results can be explained by a various demographic factors of the study participants. We have therefore listed the findings as per various sub-groups listed below.

\subsection{Normal Weight}

The effect of Ramadan fasting on body composition and body mass depends largely on the energy intake and expenditure of the subjects during the Ramadan period [5,62]. The findings from the various studies are listed in Table 3. In a study by Racinais et al., it was observed that 11 Qatari males of normal weight showed similar total daily energy expenditure before, during and after the month of Ramadan [60]. As a result, there was no significant change in body mass or composition reported. Similarly, Harder-Lauridsen et al. studied 10 men of normal weight in Denmark and found no change in body mass or composition before or after Ramadan [58]. The maintenance of body composition was found to be due to a balance in total energy intake and energy expenditure by the study participants [58].

Other studies have found a reduction in body mass and fat percentage and these discrepancies can be attributed to varying practices with regard to energy intake and expenditure during Ramadan fasting by different populations [62]. Just as some studies have shown a decrease in body weight and fat percentage during Ramadan [25], it has also been found that the effect stayed till the end of Ramadan [63]. Shehab et al., investigating the effects of Ramadan fasting on body weight, found that there were losses both in body weight and waist circumference immediately following Ramadan [64], although all the above mentioned studies had limited follow-up periods beyond Ramadan. A meta-analysis of eighty-five studies showed that Ramadan fasting can cause a significant small reduction in weight in healthy adults that has direct associations with fasting duration and correlates with season and country [65].

However, a number of studies showed that, by four to five weeks after Ramadan, the decrease in body weight and fat percentage had returned to pre-Ramadan levels $[55,66,67]$. Sadeghirad et al. did a systematic review and meta-analysis of thirty-five studies determining the changes in body mass because of Ramadan fasting and showed that weight loss did not last for more than two weeks after Ramadan [68]. It was shown that most of the subjects who lost weight regained it within two weeks and only a small amount of weight loss was maintained after Ramadan compared to the start of it [68].

This may be attributable to the fact that Ramadan fasting lasts for a period of only one month and thus there is limited impact on body mass and fat percentage. As can be seen from Table 3, studies showed less than a $5 \%$ reduction in body mass and fat percentage due to Ramadan fasting. Though the observed effect is small, it is indicative of a possible positive impact over a longer period of time. Therefore, it is worthwhile to investigate the cumulative effect of Ramadan fasting on body composition over a number of years to ascertain its clinical impact.

Studies involving physically active individuals during Ramadan fasting is of importance to understand the link between energy expenditure and body composition. Most studies in physically active individuals who exercised during Ramadan fasting showed a decrease in body mass [19,72-74]. This is likely due to dehydration and a decrease in caloric intake while maintaining training [72].

A similar trend of decreases in body fat percentage was noticed in most studies investigating the effect of Ramadan fasting on body composition in physically active individuals $[16,72,73]$. The decrease in body fat percentage is likely due to the increased utilisation of stored body fat as an energy substrate [72]. In the studies where an absence of weight change and body fat percentage was shown, the discrepancy can be explained by differences in dietary intakes, exercise regimens and methods of body fat measurements [72]. 
It can be observed form the results that there is a more consistent link between Ramadan fasting and an improvement in body composition in physically active individuals. This shows that physical activity is an important part of energy expenditure during Ramadan fasting and suggests that the greatest benefit from the fasting regime can only be obtained when volunteers undertake Ramadan fasting in combination with physical activity. Overall, it has been found that Ramadan fasting results in variable amounts of weight loss and changes in body composition in normal weight individuals, but the changes are often transient.

Other factors could also play a role in determining the effect of Ramadan fasting on body composition and mass, including gender and age [1,52]. Norouzy et al. assessed the effect of Ramadan fasting on body composition and found that males and younger individuals had a greater reduction in body weight as well as body fat percentage [52]. López-Bueno et al. studied the influence of age on body composition during Ramadan fasting and showed that there was a more pronounced reduction in body fat percentage of women over thirty years of age [51]. Husain et al. studied tropical Asiatic Muslims and found that females lost more body weight and subcutaneous fat than males [49].

Yucel et al. studied the effect of Ramadan fasting on abdominal fat distribution and found that there was a significant reduction in the visceral fat area within the sub-groups of females and individuals in their twenties [75]. Yeoh et al. showed that there was a reduction in visceral adiposity only amongst females when the results were stratified by gender [34]. In contrast, Syam et al. found that protein body mass did not significantly change due to Ramadan fasting and that weight loss was not variable according to gender [55]. It is likely that younger individuals have greater reductions in body fat percentage, as it is a factor affected directly by personal activity [75]. Young people are generally more physically active and have higher basal metabolism [75]. Additionally, many of the studies showed that females experienced a greater change in body composition, as they are likely to be more physically active than men during Ramadan fasting [75].

\subsection{Overweight and Obese}

Ramadan fasting is often practiced as a lifestyle modifier in tackling obesity among Muslim communities. The decreased frequency of meals is expected to result in lower caloric intake and eventual weight loss at the end of Ramadan. However, the effect of Ramadan fasting on the body weight and composition of obese individuals is heterogeneous, with some studies showing a loss in body weight only [41,76-79], whereas other studies show a change in body fat percentage as well [53,80-83]. This heterogeneity in the findings could be due to different dietary habits between different cultures during the month of Ramadan. The various findings are listed in Table 4. 
Table 3. Effect of Ramadan fasting on body mass and fat percentage of normal weight individuals.

\begin{tabular}{|c|c|c|c|c|c|}
\hline & Date & Country & Subjects (n) & Effect on Body Mass & Effect on Body Fat Percentage \\
\hline Bouhlel et al. [18] & 2008 & Tunisia & 9 males & Significant reduction of $1.8 \mathrm{~kg}$ & Significant reduction of $1.3 \%$ \\
\hline López-Bueno et al. [51] & 2015 & Spain & 62 females & Significant reduction of $1.6 \%$ & Significant reduction of $2.2 \%$ \\
\hline Nachvak et al. [57] & 2019 & Iran & 160 males & Significant reduction of $1.93 \mathrm{~kg}$ & Significant reduction of $0.3 \%$ \\
\hline Norouzy et al. [52] & 2013 & Iran & 240 & $\begin{array}{l}\text { Significant reduction of } 2.2 \% \text { in males and } \\
1.4 \% \text { in females aged } \leq 35 \text { years }\end{array}$ & $\begin{array}{c}\text { Significant reduction of } 2.5 \% \text { in males } \leq 35 \\
\text { years and } 1.1 \% \text { in males } 36 \text { to } 70 \text { years }\end{array}$ \\
\hline Shruthi et al. [54] & 2013 & India & 50 & Significant reduction of $0.59 \mathrm{~kg}$ & Significant reduction of $3.155 \%$ \\
\hline Syam et al. [55] & 2016 & Indonesia & 43 & Significant reduction of $0.874 \mathrm{~kg}$ & Significant reduction of $0.484 \mathrm{~kg}$ \\
\hline Kocaaga et al. [69] & 2019 & Turkey & 33 males & Significant reduction of $0.84 \mathrm{~kg}$ & Significant reduction of $1.32 \%$ \\
\hline Amiri et al. [70] & 2016 & Iran & 51 & Significant reduction of $0.78 \mathrm{~kg}$ & Significant reduction of $0.49 \mathrm{~kg}$ \\
\hline El Ati et al. [31] & 1995 & Tunisia & 16 females & No significant change & No significant change \\
\hline Harder-Lauridsen et al. [58] & 2017 & Denmark & 10 males & No significant change & No significant change \\
\hline Ramadan [59] & 2002 & Kuwait & 16 males & No significant change & No significant change \\
\hline Racinais et al. [60] & 2012 & Qatar & 11 males & No significant change & No significant change \\
\hline Finch et al. [61] & 1998 & UK & 41 & No significant change & No significant change \\
\hline Al-barha et al. [71] & 2019 & Saudi Arabia & 44 & No significant change & No significant change \\
\hline
\end{tabular}

Table 4. Effect of Ramadan fasting on body mass, body fat percentage and visceral adiposity of overweight and obese individuals.

\begin{tabular}{|c|c|c|c|c|c|c|}
\hline Authors & Date & Country & Subjects $(n)$ & Effect on Body Mass & $\begin{array}{l}\text { Effect on Body Fat } \\
\text { Percentage }\end{array}$ & $\begin{array}{l}\text { Effect on Visceral } \\
\text { Adiposity }\end{array}$ \\
\hline Khattak et al. [76] & 2012 & Malaysia & 25 & Significant reduction of $15.8 \mathrm{~kg}$ in males and $15.4 \mathrm{~kg}$ in females & No change & - \\
\hline Khan et al. [77] & 2002 & Pakistan & 10 males & Significant reduction of $3.2 \pm 1.7 \mathrm{~kg}$ & - & - \\
\hline Rohin et al. [78] & 2013 & Malaysia & 27 & $\begin{array}{l}\text { Significant reduction of } 0.95 \mathrm{~kg} \text { for overweight subjects and } \\
2.07 \mathrm{~kg} \text { in obese subjects }\end{array}$ & No change & - \\
\hline Celik et al. [80] & 2014 & Turkey & 42 & Significant reduction of $1.6 \mathrm{~kg}$ & - & - \\
\hline Suriani et al. [81] & 2015 & Malaysia & 48 & Significant reduction of $1.76 \mathrm{~kg}$ & $\begin{array}{l}\text { Significant reduction } \\
\text { of } 0.32 \%\end{array}$ & $\begin{array}{l}\text { Significant reduction } \\
\text { of } 0.75 \mathrm{~kg}\end{array}$ \\
\hline Khaled et al. [41] & 2009 & Algeria & 276 & Significant reduction of $3.12 \mathrm{~kg}$ & - & - \\
\hline Madkour et al. [82] & 2019 & UAE & 56 & Significant reduction of $1.15 \mathrm{~kg}$ & $\begin{array}{c}\text { Significant reduction } \\
\text { of } 1.22 \mathrm{~kg}\end{array}$ & $\begin{array}{c}\text { Significant reduction } \\
\text { of } 5.82 \mathrm{~cm}^{2}\end{array}$ \\
\hline Ünalacak et al. [79] & 2011 & Turkey & 10 males & Significant reduction of $2.9 \mathrm{~kg}$ & - & - \\
\hline Radhakishun et al. [83] & 2014 & Netherlands & 25 & No change & $\begin{array}{l}\text { Significant reduction } \\
\text { of } 2.5 \%\end{array}$ & - \\
\hline Salehi et al. [84] & 2007 & Iran & 28 males & Significant reduction of $6 \%$ & - & - \\
\hline Sezen et al. [53] & 2016 & Turkey & 70 & - & $\begin{array}{c}\text { Significant reduction } \\
\text { of } 0.9 \mathrm{~kg}\end{array}$ & $\begin{array}{c}\text { Significant reduction } \\
\text { of } 0.5 \%\end{array}$ \\
\hline Ganjali et al. [85] & 2016 & Iran & 24 & Significant reduction of $2.2 \pm 1.81 \mathrm{~kg}$ & - & - \\
\hline
\end{tabular}


In a study where a medium calorie balanced diet was prescribed to 28 overweight males during the month of Ramadan, fasting resulted in a significant decrease in body weight [84], indicating that the composition of the diet is important. Furthermore, a meta-analysis of 70 publications by Fernando et al. showed that there was a significant positive correlation between starting BMI and loss of weight during Ramadan fasting [66]. In the same report, there was also a significant decrease in body fat percentage among obese individuals after Ramadan as compared to before Ramadan $(-1.46$ (95\% confidence interval: -2.57 to -0.35$) \%, p=0.010$ ) [66]. Therefore, Ramadan fasting, when coupled with a balanced diet, can result in a positive change in obese individuals. However, the reductions in weight and fat mass were transient and body fat percentage returned to pre-Ramadan levels 2 to 5 weeks after the end of Ramadan. The authors explained that one possible reason for the greater weight loss in people with a higher BMI is that they have bigger glycogen stores than individuals with a lower BMI, and thus are likely to lose more body water during Ramadan fasting. Furthermore, obese individuals lose less weight as fat-free mass as compared to individuals of normal weight, thereby resulting in lower body fat percentage in the obese [66].

Therefore, Ramadan fasting results in weight loss amongst obese individuals with a possible effect on body fat percentage as well. However, most studies show that the changes in weight and body fat percentage in overweight and obese individuals are often transient and return to pre-Ramadan levels within a few weeks after the end of the Ramadan period.

\section{Metabolic Parameters}

In many regions of the world, notably Asia, the Middle East and parts of Africa, many residents are highly susceptible to pre-diabetes, diabetes and cardiovascular diseases. Therefore, for the subsequent parts of this review, we will discuss how Ramadan fasting influences glucose and lipid metabolism before, during and after Ramadan in studies from various geographical locations and with distinct dietary and lifestyle habits. We will present data not only from healthy individuals but also those at risk of various chronic conditions (e.g., obesity, type 2 diabetics, etc.).

\subsection{Glucose Homeostasis}

Some studies show that there is an increase in fasting blood glucose levels during the Ramadan fasting period [36,86], while other studies show decreases or no change $[35,50,59,86-96]$. These findings are listed in Table 5. The increased fasting blood glucose levels in Thai women, as shown by Ongsara et al., in addition to their dietary change, may be due to the decreased frequency of exercise during and after Ramadan compared with before Ramadan [86]. This is supported by research showing that exercise increases insulin sensitivity and glucose uptake into peripheral tissues [86,97]. A shift in the intake of carbohydrates from complex to more simple sugars could have also increased the levels of fasting blood glucose [36].

Furthermore, the measurement of fasting blood glucose at different times of the day could have resulted in the observed higher fasting blood glucose levels during Ramadan. In most of the studies, before the start of the Ramadan period, fasting blood glucose levels were measured in the morning, whereas during Ramadan, fasting glucose levels were measured in the evening after the daytime fast $[50,87,90]$. This difference in the time when fasting blood glucose was measured is of significance, as the glucose values in the evening may be higher due to diurnal variation [98]. Thus, fasting blood glucose measured after an overnight fast is not necessarily equivalent to that taken in the evening after Ramadan fasting and their comparison is inaccurate. Furthermore, in addition to the diurnal variation in glucose metabolism, the durations of fasting periods were also different. 
Table 5. Effect of Ramadan fasting on fasting blood glucose levels in healthy subjects.

\begin{tabular}{ccccc}
\hline Authors & Date & Country & Subjects $(\boldsymbol{n})$ & $\begin{array}{c}\text { Effect of Ramadan } \\
\text { Fasting on Fasting Blood } \\
\text { Glucose Levels }\end{array}$ \\
\hline Ongsara et al. [86] & 2017 & Thailand & 65 & Increase \\
Fakhrzadeh et al. [50] & 2003 & Iran & 91 & Decrease \\
Larijani et al. [87] & 2003 & Iran & 115 & Decrease \\
Sarraf-Zadegan et al. [89] & 2000 & Iran & 50 & No change \\
Ziaee et al. [90] & 2006 & Iran & 81 & Decrease \\
Azizi and Rasouli [91] & 1987 & Iran & 9 & No change \\
Kiyani et al. [92] & 2017 & Pakistan & 80 & Decrease \\
Ramadan [59] & 2002 & Kuwait & 16 & No change \\
Lamine et al. [35] & 2006 & Tunisia & 30 & No change \\
Beltaifa et al. [93] & 2002 & Tunisia & 20 & No change \\
Roy et al. [96] & 2017 & India & 37 males & Decrease \\
Darzabi et al. [99] & 2019 & Iran & 15 males & Decrease \\
\hline
\end{tabular}

In a study of twenty healthy males during Ramadan fasting, it was revealed that there were significant decreases in fasting plasma insulin and glucose by $52.8 \%$ and 12.3 , respectively $(p<0.01)$ [100] and, consequently, a decrease in insulin resistance using HOMA-IR (Homeostatic Model Assessment of Insulin Resistance, $p<0.01$ ), which the authors believed was due to calorie restrictions. However, this study also showed reductions in fasting adiponectin by $45.6 \%$, which was in fact positively associated with decreases in body weight. These results suggested that Ramadan fasting can help with maintaining glucose homeostasis among young people [100].

In type 2 diabetics, however, Ramadan fasting leads to much more variable changes, with some studies finding negligible changes in glycaemic control [83,101-104], whereas others show improvements [88,105-107]. These findings are listed in Table 6. The effects of no change in glycaemic control have often been substantiated with evidence showing that $\mathrm{HbA} 1 \mathrm{c}$ values and fructosamine did not change during Ramadan fasting $[103,108,109]$. However, the time frame for the $\mathrm{HbA1c}$ analyses of about 4 weeks during the month of Ramadan is not long enough to give an appropriate reflection of glycaemic control, thus leading to uncertainties in the findings.

On the other hand, continuous glucose monitoring (CGM) may be a better reflection of glycaemic control within the time frame of Ramadan. Pallayova et al. studied glucose homeostasis before, during and after Ramadan with CGM in non-diabetic adults and reported a higher hyperglycaemic area under the curve after Ramadan than before and during [111]. Hassanein et al. investigated the risk of Ramadan fasting in diabetics through the use of CGM and found that there was a significantly higher occurrence and prolonged duration of hypoglycaemia during Ramadan fasting [112]. Similarly, there are other studies reporting acute adverse events, such as severe hyperglycaemia or hypoglycaemia, in diabetic patients during Ramadan $[113,114]$. A population-based study of diabetes and its characteristics during Ramadan fasting in 13 countries revealed that severe hypoglycaemia was significantly more common during Ramadan than in other months (type 1 diabetes, 0.14 vs. 0.03 episodes/month, $p=0.0174$; type 2 diabetes, 0.03 vs. 0.004 episodes/month, $p<0.0001$ ) [113].

These results suggest that Ramadan fasting is likely to cause substantial changes in glycaemic control in type 2 diabetics and therefore their meal patterns require particular attention. This is because when food is eaten at the breaking of fast, blood glucose increases drastically, followed by overnight hyperglycaemia due to late-night eating, while the meal taken before dawn causes prolonged glucose decay in the daytime [115]. This pattern of glycaemic increase and decrease is more common among diabetic patients under medication and in patients who have poor control of their condition or do not comply with lifestyle recommendations $[115,116]$. Hence, from a religious and cultural point of view, Ramadan fasting is encouraged in healthy individuals and those with health conditions are exempted from this fasting ritual. 
Table 6. Effect of Ramadan fasting on fasting blood glucose levels in subjects with health conditions.

\begin{tabular}{|c|c|c|c|c|c|}
\hline Authors & Date & Country & $\begin{array}{l}\text { Subjects } \\
\text { (n) }\end{array}$ & $\begin{array}{l}\text { Health } \\
\text { Condition }\end{array}$ & $\begin{array}{c}\text { Effect of Ramadan } \\
\text { Fasting on Fasting } \\
\text { Blood Glucose } \\
\text { Levels }\end{array}$ \\
\hline Sadiya et al. [36] & 2011 & UAE & 19 & $\begin{array}{l}\text { Metabolic } \\
\text { syndrome }\end{array}$ & Increase \\
\hline Shariatpanahi et al. [88] & 2008 & Iran & 55 & $\begin{array}{l}\text { Metabolic } \\
\text { syndrome }\end{array}$ & Decrease \\
\hline Radhakishun et al. [83] & 2014 & Netherlands & 25 & Obesity & No change \\
\hline Mafauzy et al. [101] & 1990 & Malaysia & 22 & Type 2 diabetes & No change \\
\hline Lessan et al. [102] & 2015 & UAE & 56 & Type 2 diabetes & No change \\
\hline Al-Hader et al. [103] & 1994 & Jordan & 23 & Type 2 diabetes & No change \\
\hline Yarahmadi et al. [104] & 2003 & Iran & 57 & Type 2 diabetes & No change \\
\hline Khatib and Shafagoj [106] & 2004 & Jordan & 44 & Type 2 diabetes & Decrease \\
\hline Khaled et al. [107] & 2006 & Algeria & 60 & $\begin{array}{l}\text { Obesity and } \\
\text { Type } 2 \text { diabetes }\end{array}$ & Decrease \\
\hline Norouzy et al. [110] & 2012 & Iran & 89 & Type 2 diabetes & Increase \\
\hline
\end{tabular}

It should be noted, however, that previous studies of Ramadan fasting in type 2 diabetics were often influenced by recall bias, and up to two-thirds of the patients either maintained or increased their insulin dosing during Ramadan, which could be one of the reasons for the increased incidence of severe hypoglycaemia [105,117]. There are, however, some studies which indicated that the prevalence of severe hyperglycaemia or hypoglycaemia during Ramadan was low among diabetic patients $[36,105,118]$. A study in Pakistan investigating the glycaemic levels of patients with diabetes during Ramadan fasting showed that the incidence of hyperglycaemia was $19.8 \%$ and hypoglycaemia was $21.7 \%$ and that less than $10 \%$ had major hypoglycaemic and hyperglycaemic episodes [119].

Therefore, the results suggest that Ramadan fasting has variable impacts on glucose homeostasis in both healthy and diabetic individuals and that the specific food choices and lifestyle factors, as part of the fasting regime, could also play important roles. In order to achieve better glucose homeostasis, it is recommended that there be an increased intake of fruits and vegetables high in complex carbohydrates and a decreased intake of simple sugars [86].

\subsection{Lipid Profile}

Studies investigating the effect of Ramadan fasting on the lipid profile have been promising, as most of them show improvements in high density lipoprotein (HDL) and low density lipoprotein (LDL) cholesterol levels after one month of Ramadan [30,44,50,64,120-132]. The various studies are listed in Table 7.

The increase in HDL cholesterol levels can be explained by the post-prandial lipaemia changes that occur during Ramadan fasting [126]. Since the amount of post-prandial lipaemia has been shown to be of great importance to lipid metabolism and HDL levels in plasma [146], the larger magnitude and duration of lipaemia during the gorging meal, followed by longer absorptive-free hours during fasting, results in a net balance that is more efficient in the metabolism of triglyceride (TG) rich lipoproteins [126]. This could be the reason for the observed increased plasma HDL cholesterol levels in many of the studies. 
Table 7. Effect of Ramadan fasting on lipid profile in healthy individuals.

\begin{tabular}{|c|c|c|c|}
\hline Authors & Date & Subjects (n) & Effect of Ramadan on Parameters \\
\hline Adlouni et al. [44] & 1997 & 32 males & $\begin{array}{c}\text { Increase in HDL } \\
\text { Reductions in TC, TG and LDL }\end{array}$ \\
\hline Akaberi et al. [129] & 2014 & 43 & $\begin{array}{l}\text { Increases in TC, HDL and LDL } \\
\text { No change in TG } \\
\text { Reductions in LDL/HDL and TG/HDL }\end{array}$ \\
\hline Akanji et al. [125] & 2000 & 64 & $\begin{array}{c}\text { Increases in apo A-1, apo A-1/apo B, apo } \\
\text { A-1/HDL } \\
\text { No change in TC, TG or LDL }\end{array}$ \\
\hline Al Hourani et al. [133] & 2009 & 57 females & $\begin{array}{c}\text { No change in TC, HDL or LDL } \\
\text { Reduction in TG }\end{array}$ \\
\hline Asgary et al. [134] & 2000 & 50 males & Reductions in TC and TG \\
\hline Dowood [131] & 2004 & 60 & $\begin{array}{c}\text { No change in TC, TG, HDL or VLDL } \\
\text { Reduction in LDL }\end{array}$ \\
\hline Fakhrzadeh et al. [50] & 2003 & 91 & $\begin{array}{c}\text { Increase in HDL } \\
\text { Reductions in TC, TG and LDL }\end{array}$ \\
\hline Furuncuoglu et al. [135] & 2007 & 39 & $\begin{array}{c}\text { No change in HDL } \\
\text { Reductions in TC and TG }\end{array}$ \\
\hline Haghdoost and Poorranjbar [74] & 2009 & 93 & Reduction in TG \\
\hline Haouari-Oukerro et al. [121] & 2013 & 38 males & $\begin{array}{c}\text { Increase in HDL } \\
\text { No change in TC } \\
\text { Reductions in TG and LDL }\end{array}$ \\
\hline Hosseini and Hejazi [132] & 2013 & 26 males & $\begin{array}{c}\text { Increase in HDL } \\
\text { Reductions in TC, LDL, VLDL, LDL/HDL } \\
\text { and TC/HDL }\end{array}$ \\
\hline Lamri-Senhadji et al. [120] & 2009 & 46 & $\begin{array}{l}\text { Increase in HDL } \\
\text { Reduction in LDL }\end{array}$ \\
\hline Mahoob et al. [136] & 1999 & 35 males & $\begin{array}{c}\text { Reductions in TG, LDL, TC/HDL and } \\
\text { LDL/HDL }\end{array}$ \\
\hline M Maislos et al. [126] & 1998 & 22 & $\begin{array}{c}\text { Increase in HDL } \\
\text { No change in TC, TG, LDL or VLDL }\end{array}$ \\
\hline M Maislos et al. [123] & 1993 & 24 & $\begin{array}{c}\text { Increases in HDL, apo A-1 } \\
\text { No change in TC, TG, LDL or VLDL } \\
\text { Reductions in TC/HDL and LDL/HDL }\end{array}$ \\
\hline Mansi [122] & 2007 & 70 & $\begin{array}{l}\text { Increase in HDL } \\
\text { No change in TC or TG } \\
\text { Reduction in LDL }\end{array}$ \\
\hline Nematy et al. [130] & 2012 & 82 & $\begin{array}{c}\text { Increase in HDL } \\
\text { Reductions in TC, TG, LDL and VLDL }\end{array}$ \\
\hline Qujeq et al. [128] & 2002 & 83 & $\begin{array}{l}\text { Increase in HDL } \\
\text { Reduction in LDL }\end{array}$ \\
\hline Rahman et al. [30] & 2004 & 20 males & $\begin{array}{c}\text { Increase in HDL } \\
\text { No change in TC, TG or LDL } \\
\text { Reductions in TC/LDL and LDL/HDL }\end{array}$ \\
\hline Saleh et al. [137] & 2005 & 60 & $\begin{array}{l}\text { No change in TG, HDL or VLDL } \\
\text { Reductions in TC and LDL }\end{array}$ \\
\hline Shehab et al. [64] & 2012 & 65 & $\begin{array}{c}\text { Increase in HDL } \\
\text { No change in TC } \\
\text { Reductions in TG and LDL }\end{array}$ \\
\hline
\end{tabular}


Table 7. Cont.

\begin{tabular}{|c|c|c|c|}
\hline Authors & Date & Subjects (n) & Effect of Ramadan on Parameters \\
\hline Temizhan et al. [127] & 2000 & 52 & $\begin{array}{c}\text { No change in HDL } \\
\text { Reductions in TC, TG, LDL and VLDL }\end{array}$ \\
\hline Ünalacak et al. [79] & 2011 & 20 males & $\begin{array}{c}\text { No change in TC, HDL or LDL } \\
\text { Reduction in TG }\end{array}$ \\
\hline Zare et al. [124] & 2011 & 32 males & $\begin{array}{c}\text { Increases in HDL and HSP70 } \\
\text { Reductions in TC, TG, LDL, LDL/HDL } \\
\text { and TC/HDL }\end{array}$ \\
\hline Ziaee et al. [90] & 2006 & 81 & $\begin{array}{c}\text { Increase in LDL } \\
\text { No change in TC, TG or VLDL } \\
\text { Reduction in HDL }\end{array}$ \\
\hline Thannoun et al. [138] & 2010 & 31 & $\begin{array}{c}\text { Increase in HDL } \\
\text { Reduction in TC, LDL and TG }\end{array}$ \\
\hline Marbut et al. [139] & 2006 & 30 males & $\begin{array}{l}\text { Increase in HDL } \\
\text { Reduction in LDL }\end{array}$ \\
\hline Akhtaruzzaman et al. [140] & 2014 & 28 females & $\begin{array}{c}\text { Increase in HDL } \\
\text { Reduction in TC and LDL }\end{array}$ \\
\hline Ismail et al. [141] & 2014 & 31 & $\begin{array}{c}\text { Increase in HDL } \\
\text { Reduction in LDL and TG }\end{array}$ \\
\hline Pathan et al. [142] & 2010 & 30 males & $\begin{array}{c}\text { Increase in HDL } \\
\text { Reduction in TC, LDL, VLDL and TG }\end{array}$ \\
\hline Dowod [131] & 2004 & 60 & Reduction in LDL \\
\hline Shahsavan et al. [143] & 2015 & 89 & $\begin{array}{c}\text { Reduction in TC and HDL } \\
\text { No change in LDL, TG or LDL/HDL }\end{array}$ \\
\hline Khan et al. [144] & 2017 & Pakistan & $\begin{array}{l}\text { Increase in LDL } \\
\text { Reduction in HDL }\end{array}$ \\
\hline Indra et al. [145] & 2007 & Indonesia & Reduction in TC, LDL and TG \\
\hline
\end{tabular}

TC: Total cholesterol, TG: Triglycerides, HDL: High density lipoprotein, LDL: Low density lipoprotein, VLDL: Very low density lipoprotein.

In addition, the effect of Ramadan fasting on lipid profile was shown to extend to even after Ramadan. Shehab et al. found that there was a significant increase in HDL and a decrease in LDL cholesterol levels a month after Ramadan fasting [64]. These results suggest that Ramadan fasting may be a suitable lifestyle modification to improve blood lipid profile $[64,129,147]$. Thus, future studies evaluating the effect of Ramadan fasting in people with lipid disorders is of importance [129].

However, a cohort study by Ziaee et al. of 81 students found that there was a decrease in HDL and an increase in LDL levels during Ramadan fasting [90]. The contradiction in the results may be due to a change in the dietary regimen during Ramadan, decreased physical activity and cultural influence on dietary patterns $[90,133,148]$. Haghdoost et al. studied the connection between physical activity and Ramadan fasting on the lipid profile and found that total cholesterol levels decreased significantly during and after Ramadan for subjects who were physically active while fasting (by -12.24 and $-8.4 \mathrm{mg} / \mathrm{dL}$, respectively) [74]. However, the patterns of changes in HDL and LDL cholesterol were more or less comparable in both physically active and inactive groups [74]. This finding shows that the observed reduction in total cholesterol was probably due to reductions in TG levels and physical activity may have been the effect modifier.

In fact, several studies showed a decrease in TG levels during Ramadan fasting [44,64,74,79,121,124,133-136], although other studies found no change $[90,122,123,125,129,131,137]$. Two studies did observe an increase in serum TG, which may be due to the consumption of foods rich in carbohydrates accompanied by less physical activity during Ramadan $[90,129]$. This is linked back with studies showing that 
people are more likely to consume carbohydrate-rich foods during Ramadan [33,90,149-151]. Hallak and Namoni showed a positive correlation between serum triglyceride levels and sugar intake during Ramadan $[135,152]$. The increase in blood triglycerides with high sugar consumption was also observed by Albrink and Ullrich $[135,153]$. Alternatively, the lipolytic effect of fasting for long periods of time may result in higher serum triglyceride levels at the end of Ramadan fasting [131,154].

In cases where a decrease in TG levels was found, it could be due to the increased consumption of monounsaturated and polyunsaturated fatty acids, as well as the decreased consumption of saturated fatty acids [64]. This was likely to be so in a study from Morocco, where a significant decrease in triglyceride levels was observed even after the month of Ramadan [44,64]. It seems as though the type of fat intake during Ramadan determines the resulting blood cholesterol level [131].

Thus, the variations in the lipid profile before and after Ramadan in healthy individuals are often attributed to differences in dietary habits between countries, like that of the classic Mediterranean diet in Morocco and the diet high in saturated fat in affluent countries of the Arabian Gulf states [64,137]. These differences could also be explained by the fact that the duration of fasting differs among countries depending on the seasonal climate following the lunar calendar [137]. This reiterates the fact that Ramadan fasting and the breaking of fast is practised differently in different populations and has varying impacts on the health outcomes of those who fast.

Overall, there is a potential for a favourable impact on cardiometabolic risk factors due to improved lipid profile during Ramadan fasting. A meta-analysis by Kul et al. found that Ramadan fasting resulted in lower LDL cholesterol levels in both males and females, as well as all of the subjects [155]. Additionally, HDL cholesterol levels were also increased among females, whereas triglycerides (TGs) decreased to a small extent in among males only. Overall, this caused a rise in total cholesterol [155]. Similarly, a review by Mazidi et al. found that the majority of studies reported an increase in HDL levels, a decrease in triglyceride levels and no change or a decline in total cholesterol and LDL levels [156].

Beyond blood lipid profile, a systematic review investigating the effect of Ramadan fasting on cardiometabolic risk factors showed that, generally, the effects may be described as beneficial or neutral, although there were some exceptions [157]. In fact, three studies investigating the effects of Ramadan fasting on blood pressure, a risk factor for cardiometabolic diseases, reported a significant drop in systolic blood pressure during Ramadan fasting, while most studies revealed no change in blood pressure [157]. Furthermore, a prospective observational study showed significant changes in some cardiovascular risk factors during Ramadan fasting, including an improvement in 10-year coronary heart disease risk (based on Framingham risk score) and a reduction in systolic blood pressure, body mass index and waist circumference, although C-reactive protein (CRP) and homocysteine were not significantly different [130]. Ramadan fasting has also been shown to have some beneficial effects on endothelial function, like improved nitric oxide availability, which can affect cardiometabolic risk [158]. Some studies investigated the effect of Ramadan fasting on inflammatory markers and showed that there was a significant reduction in CRP levels, the attenuation of proinflammatory cytokines, a decrease in IGF- 1 and IL-2 levels, an increase in adiponectin, a decrease in TNF- $\alpha$ and a reduction of serum amyloid A and protein carbonyl group levels [159-163]. However, the effects are not conclusive and an improvement in cardiometabolic risk factors cannot be substantiated by current studies due to several limitations. This is because prospective studies carried out over a long period of time are lacking and the studies are generally small in size [157].

\section{Overweight and Obese}

Given that overweight and obese individuals are likely to respond differently compared to normal weight individuals to various dietary interventions, in this section we will specifically discuss the changes in lipid profile due to Ramadan fasting in overweight and obese individuals. A study conducted on 103 obese individuals in Egypt showed that Ramadan fasting resulted in a significant improvement in total cholesterol, total triglycerides, high density lipoprotein, low density lipoprotein, TC/HDL ratio, LDL/HDL ratio, lipoprotein a, apolipoprotein, apolipoprotein B levels and coagulation parameters, 
which continued for four weeks after fasting [164]. Similarly, in another study on 60 obese women with type 2 diabetes in Algeria, Ramadan fasting resulted in a significant improvement in glucose homeostasis, although total cholesterol, triglycerides and LDL levels also increased significantly [107]. Ramadan fasting has also been shown to increase the genetic expression of anti-inflammatory, antioxidant and metabolic regulatory genes in overweight and obese individuals [79,165].

Leptin levels are important in regulating the long-term deposition of fat but the effect of Ramadan fasting on leptin levels is not well established [166]. Kassab et al. showed that serum leptin levels increased significantly by $37 \%$ during Ramadan fasting in obese individuals [166]. In contrast, Alzoghaibi et al. observed a significant drop in plasma leptin levels during Ramadan fasting [167]. Even though the loss of weight typically results in a drop in serum leptin levels, in the case of obese individuals, increased fat oxidation and increased serum leptin were correlated [168]. As such, it is not clear how Ramadan fasting affects serum leptin levels and the eventual deposition of fat in obese people and more future studies in this area are recommended.

\section{Discussion}

Ramadan fasting is a mandatory practice for all healthy Muslims and it is one of the five pillars of Islam. Its uniqueness as a type of time-restricted feeding results in dietary habits that are unlike any other type of fasting or time-restricted feeding diet. In particular, Ramadan fasting leads to changes in nutrient intake and the composition of the diet, although the changes are variable based on location, as well as culture.

The effect of Ramadan fasting on health outcomes is an important investigation to understand the link between abstaining from food and water during daylight hours for an entire month and human physiology. Furthermore, the high occurrence of cardiovascular diseases in Muslim communities makes these investigations particularly pertinent [157]. Whilst recognising that fasting during Ramadan is not an experimentally rigorous time-restricted feeding regimen, its advantage is the availability of a very large number of datasets. Recognising potential bias, it is fair to assume that, due to the religious conviction, most will comply with time-restricted fasting.

Ramadan fasting has been shown to be of some benefit, as it causes significant reductions in body mass in healthy and obese individuals and, in some cases, reductions in body fat percentage as well. This can be explained by the fact that the human body adapts during fasting to slow down basal metabolism and utilise fats more efficiently in conditions of negative energy balance [131]. The most promising health outcome due to Ramadan fasting appears to be an improvement in lipid profile, which often extends even after the month of Ramadan fasting. An improvement in lipid profile could be beneficial for the cardiovascular system, as HDL is protective against coronary heart disease [95,169].

The results for glucose homeostasis are more conflicting and there are only a few studies showing an improvement in fasting blood glucose levels and, given that fasting measurements are often measured at different times pre- and post-Ramadan fasting, this is of some concern in the interpretation of these findings. Furthermore, inconsistencies in the results of the various studies investigating the effects of Ramadan fasting on health outcomes can be explained by the abovementioned limitations, such as differences in the duration of fasting caused by seasons and climate, variations in dietary habits and socioeconomic status, different study methodology and the age and gender of the individuals, as well as other health and lifestyle factors [157].

When comparing Ramadan fasting to other types of intermittent fasting, such as alternate day fasting, time-restricted feeding (e.g., feeding during daylight hours only) and modified fasting regimens, it can be observed that the effect on body mass and composition is more pronounced in the other types of intermittent fasting [170]. Many of the studies involving other types of intermittent fasting show weight loss that is less transient than Ramadan fasting [170]. However, the effects of the other types of intermittent fasting on metabolic parameters are mixed and no more conclusive than Ramadan fasting [170]. 
One of the limitations of investigating the effect of Ramadan fasting on health outcomes is the lack of longer-term prospective studies. For example, the cumulative longer-term effects of Ramadan fasting for 1 month every year for several years are yet to be established. Indeed, this is an area of focus that should be investigated in future studies and is of significance in understanding the longer-term health implications of Ramadan fasting over a number of years. Another limitation of studies involving Ramadan fasting is that many of them do not have controls, thus resulting in further limitations to the data [157]. This is because it is problematic to compare fasting and non-fasting individuals or include randomisation in the study procedure [157].

Overall, this review shows that there are some aspects of Ramadan fasting that result in an improvement in health outcomes. The type of diet, in particular, is an important arbitrator of the effect of Ramadan fasting on health. In cases where there were positive changes in diet during Ramadan, there were observed improvements in health outcomes. In particular, it is recommended in Islam to have a balanced diet rich in fruits and vegetables. Studies that showed improvements in body composition or metabolic parameters were found to have fruit- and vegetable-rich diets, thus following these recommendations more closely $[64,137]$. On the other hand, studies of Ramadan fasting in countries with diets rich in saturated fat did not show favourable results [64,137].

Furthermore, it is recommended in Islam to have moderate food intake and be physically active during Ramadan. The positive effect of physical activity during Ramadan fasting can be observed in studies involving physically active individuals, where a decrease in body fat percentage was observed in most cases $[16,72,73]$. As such, there are many different conditions that play a part in Ramadan fasting and have varied effects on health outcomes. All these factors need to be kept in mind while following an optimal Ramadan fasting regime to obtain the maximal health benefits that this religious practice is meant to impart.

Author Contributions: Conceptualisation C.J.H., S.H. and F.O.; methodology C.J.H. and S.H.; validation F.O., C.J.H. and S.H.; formal analysis F.O.; investigation FO.; resources C.J.H.; data curation F.O.; writing-original draft preparation F.O.; writing - review and editing C.J.H. and S.H.; supervision C.J.H.; project administration S.H. All authors have read and agreed to the published version of the manuscript.

Funding: This research has been funded by Wilmar International Ltd.

Conflicts of Interest: The authors declare no conflict of interest. The funders had no role in the design of the study; in the collection, analyses, or interpretation of data; in the writing of the manuscript, or in the decision to publish the results.

\section{References}

1. Meo, S.A.; Hassan, A. Physiological changes during fasting in Ramadan. J. Pak. Med. Assoc. 2015, 65, S6-S14.

2. Dikensoy, E.; Balat, O.; Cebesoy, B.; Ozkur, A.; Cicek, H.; Can, G. The effect of Ramadan fasting on maternal serum lipids, cortisol levels and fetal development. Arch. Gynecol. Obstet. 2009, 279, 119. [CrossRef]

3. Prior, R. Ramadan: A History. CNN. 2019. Available online: https://edition.cnn.com/2019/05/05/world/ history-of-ramadan-trnd/index.html (accessed on 24 July 2020).

4. Baines, W. The Origins of Ramadan. Available online: https://www.beliefnet.com/faiths/islam/the-origins-oframadan.aspx (accessed on 24 July 2020).

5. Alkandari, J.R.; Maughan, R.J.; Roky, R.; Aziz, A.R.; Karli, U. The implications of Ramadan fasting for human health and well-being. J. Sports Sci. 2012, 30, S9-S19. [CrossRef]

6. Gabel, K.; Hoddy, K.K.; Haggerty, N.; Song, J.; Kroeger, C.M.; Trepanowski, J.F.; Panda, S.; Varady, K.A. Effects of 8-hour time restricted feeding on body weight and metabolic disease risk factors in obese adults: A pilot study. Nutr. Healthy Aging 2018, 4, 345-353. [CrossRef]

7. Chaix, A.; Zarrinpar, A.; Miu, P.; Panda, S. Time-restricted feeding is a preventative and therapeutic intervention against diverse nutritional challenges. Cell Metab. 2014, 20, 991-1005. [CrossRef]

8. Rothschild, J.; Hoddy, K.K.; Jambazian, P.; Varady, K.A. Time-restricted feeding and risk of metabolic disease: A review of human and animal studies. Nutr. Rev. 2014, 72, 308-318. [CrossRef] 
9. Moro, T.; Tinsley, G.; Bianco, A.; Marcolin, G.; Pacelli, Q.F.; Battaglia, G.; Palma, A.; Gentil, P.; Neri, M.; Paoli, A. Effects of eight weeks of time-restricted feeding (16/8) on basal metabolism, maximal strength, body composition, inflammation, and cardiovascular risk factors in resistance-trained males. J. Transl. Med. 2016, 14, 290. [CrossRef]

10. Trepanowski, J.F.; Bloomer, R.J. The impact of religious fasting on human health. Nutr. J. 2010, 9, 57. [CrossRef]

11. Ibrahim, N.S.I.; Hardinsyah, H.; Setiawan, B. Hydration status and liver function of young men before and after Ramadan fasting. J. Gizi Dan Pangan 2018, 13, 33-38. [CrossRef]

12. Mustafa, K.; Mahmoud, N.; Gumaa, K.; Gader, A. The effects of fasting in Ramadan: 2. Fluid and electrolyte balance. Br. J. Nutr. 1978, 40, 583-589. [CrossRef]

13. Leiper, J.B.; Molla, A. Effects on health of fluid restriction during fasting in Ramadan. Eur. J. Clin. Nutr. 2003, 57, S30-S38. [CrossRef]

14. Hosseini, S.R.A.; Sardar, M.A.; Hejazi, K.; Farahati, S. The effect of Ramadan fasting and physical activity on body composition, serum osmolarity levels and some parameters of electrolytes in females. Int. J. Endocrinol. Metab. 2013, 11, 88.

15. Dikme, O.; Fasting, D.O.R. Its influence on serum osmolality in emergency patients. J. Emerg Med. Crit. Care 2016, 2, 4 .

16. Trabelsi, K.; El Abed, K.; Trepanowski, J.F.; Stannard, S.R.; Ghlissi, Z.; Ghozzi, H.; Masmoudi, L.; Jammoussi, K.; Hakim, A. Effects of Ramadan fasting on biochemical and anthropometric parameters in physically active men. Asian J. Sports Med. 2011, 2, 134. [CrossRef] [PubMed]

17. Azwany, N.; Aziz, A.; Mohammad, W. The Impact of ramadan fasting on hydration status of type 2 diabetics in kubang kerian, kelantan. J. Kesihat. Masy. 2004, 10, 31-34.

18. Bouhlel, E.; Denguezli, M.; Zaouali, M.; Tabka, Z.; Shephard, R.J. Ramadan fasting's effect on plasma leptin, adiponectin concentrations, and body composition in trained young men. Int. J. Sport Nutr. Exerc. Metab. 2008, 18, 617-627. [CrossRef]

19. Ramadan, J.; Telahoun, G.; Al-Zaid, N.S.; Barac-Nieto, M. Responses to exercise, fluid, and energy balances during Ramadan in sedentary and active males. Nutrition 1999, 15, 735-739. [CrossRef]

20. Abushady, M.; Samy, M.; Bekhet, M.; Abdullah, A. Effect of Ramadan fasting on renal function in patients with type 2 diabetes. Diabetes Res. Clin. Pract. 2019, 153, 176-183. [CrossRef]

21. Shao, Y.; Lim, G.J.; Chua, C.L.; Wong, Y.F.; Yeoh, E.C.K.; Low, S.K.M.; Sum, C.F. The effect of Ramadan fasting and continuing sodium-glucose co-transporter-2 (SGLT2) inhibitor use on ketonemia, blood pressure and renal function in Muslim patients with type 2 diabetes. Diabetes Res. Clin. Pract. 2018, 142, 85-91. [CrossRef]

22. NasrAllah, M.M.; Osman, N.A. Fasting during the month of Ramadan among patients with chronic kidney disease: Renal and cardiovascular outcomes. Clin. Kidney J. 2014, 7, 348-353. [CrossRef]

23. Alawadi, F.; Rashid, F.; Bashier, A.; Abdelgadir, E.; Al Saeed, M.; Abuelkheir, S.; Khalifa, A.; Bachet, F.; Elsayed, M.; Abdallah, K. The use of Free Style Libre Continues Glucose Monitoring (FSL-CGM) to monitor the impact of Ramadan fasting on glycemic changes and kidney function in high-risk patients with diabetes and chronic kidney disease stage 3 under optimal diabetes care. Diabetes Res. Clin. Pract. 2019, 151, 305-312. [CrossRef] [PubMed]

24. Eldeeb, A.A.; Mahmoud, M.A.; Ibrahim, A.B.; Yousef, E.A.; Sabry, A.A. Effect of Ramadan fasting on arterial stiffness parameters among Egyptian hypertensive patients with and without chronic kidney disease. Saudi J. Kidney Dis. Transplant. 2020, 31, 582.

25. Al-Hourani, H.; Atoum, M. Body composition, nutrient intake and physical activity patterns in young women during Ramadan. Singap. Med. J. 2007, 48, 906.

26. Foundation, B.N. Traditional Ramadan Foods from around the World. Available online: https://www. nutrition.org.uk/healthyliving/seasons/ramadan.html?start=1 (accessed on 26 February 2020).

27. Bakhotmah, B.A. The puzzle of self-reported weight gain in a month of fasting (Ramadan) among a cohort of Saudi families in Jeddah, Western Saudi Arabia. Nutr. J. 2011, 10, 84. [CrossRef]

28. Ali, Z.; Abizari, A.-R. Ramadan fasting alters food patterns, dietary diversity and body weight among Ghanaian adolescents. Nutr. J. 2018, 17, 75. [CrossRef]

29. Pirsaheb, S.; Pasdar, Y.; Navabi, S.J.; Rezaei, M.; Darbandi, M.; Niazi, P. Fasting consequences during Ramadan on lipid profile and dietary patterns. J. Nutr. Fasting Health 2013, 1, 6-12. 
30. Rahman, M.; Rashid, M.; Basher, S.; Sultana, S.; Nomani, M. Improved serum HDL cholesterol profile among Bangladeshi male students during Ramadan fasting. EMHJ East. Mediterr. Health J. 2004, 10, 131-137.

31. El Ati, J.; Beji, C.; Danguir, J. Increased fat oxidation during Ramadan fasting in healthy women: An adaptative mechanism for body-weight maintenance. Am. J. Clin. Nutr. 1995, 62, 302-307. [CrossRef]

32. Sweileh, N.; Schnitzler, A.; Hunter, G.; Davis, B. Body composition and energy metabolism in resting and exercising muslims during Ramadan fast. J. Sports Med. Phys. Fit. 1992, 32, 156-163.

33. Frost, G.; Pirani, S. Meal frequency and nutritional intake during Ramadan: A pilot study. Hum. Nutrition. Appl. Nutr. 1987, 41, 47-50.

34. Yeoh, E.; Zainudin, S.B.; Loh, W.N.; Chua, C.L.; Fun, S.; Subramaniam, T.; Sum, C.F.; Lim, S.C. Fasting during Ramadan and associated changes in glycaemia, caloric intake and body composition with gender differences in Singapore. Ann. Acad. Med. Singap. 2015, 44, 202-206. [PubMed]

35. Lamine, F.; Bouguerra, R.; Jabrane, J.; Marrakchi, Z.; Ben, M.R.; Ben, C.S.; Gaigi, S. Food intake and high density lipoprotein cholesterol levels changes during ramadan fasting in healthy young subjects. La Tunis. Médicale 2006, 84, 647-650.

36. Sadiya, A.; Ahmed, S.; Siddieg, H.H.; Babas, I.J.; Carlsson, M. Effect of Ramadan fasting on metabolic markers, body composition, and dietary intake in Emiratis of Ajman (UAE) with metabolic syndrome. Diabetes Metab. Syndr. Obes. 2011, 4, 409-416. [CrossRef] [PubMed]

37. Bouhlel, E.; Salhi, Z.; Bouhlel, H.; Mdella, S.; Amamou, A.; Zaouali, M.; Mercier, J.; Bigard, X.; Tabka, Z.; Zbidi, A. Effect of Ramadan fasting on fuel oxidation during exercise in trained male rugby players. Diabetes Metab. 2006, 32, 617-624. [CrossRef]

38. Poh, B.; Zawiah, H.; Ismail, M.; Henry, C. Changes in body weight, dietary intake and activity pattern of adolescents during Ramadan. Malays. J. Nutr. 1996, 2, 1-10.

39. Suriani, I.; Shamsuddin, K.; Abdul Latif, K.; Saad, H.A. The effect of the Malaysian Food Guideline guidance on a group of overweight and obese women during Ramadan. Saudi Med. J. 2015, 36, 40-45. [CrossRef]

40. Savas, E.; Öztürk, Z.A.; Tanrıverdi, D.; Kepekçi, Y. Do Ramadan fasting restrictions alter eating behaviours in obese women? J. Relig. Health 2014, 53, 135-140. [CrossRef]

41. Khaled, B.M.; Belbraouet, S. Effect of Ramadan fasting on anthropometric parameters and food consumption in 276 type 2 diabetic obese women. Int. J. Diabetes Dev. Ctries. 2009, 29, 62. [CrossRef]

42. Karaagaoglu, N.; Yucecan, S. Some behavioral changes observed among fasting subjects, their nutritional habits and energy expenditure in Ramadan. Int. J. Food Sci. Nutr. 2000, 51, 125.

43. Khattak, M.M.A.K.; Mamat, N.M.; Bakar, W.A.M.A.; Shaharuddin, M.F.N. Does religious fasting affect energy and macro-nutrients intakes? Nutr. Food Sci. 2013, 43, 254-260. [CrossRef]

44. Adlouni, A.; Ghalim, N.; Benslimane, A.; Lecerf, J.M.; Saïle, R. Fasting during Ramadan induces a marked increase in high-density lipoprotein cholesterol and decrease in low-density lipoprotein cholesterol. Ann. Nutr. Metab. 1997, 41, 242-249. [CrossRef] [PubMed]

45. Aksungar, F.B.; Eren, A.; Ure, S.; Teskin, O.; Ates, G. Effects of intermittent fasting on serum lipid levels, coagulation status and plasma homocysteine levels. Ann. Nutr. Metab. 2005, 49, 77-82. [CrossRef] [PubMed]

46. Shalaei, N.; Motaghedi Larijani, A.; Mohajeri, S.A.R.; Norouzy, A.; Nematy, M.; Sheikhol Vaezin, F.; Jahandoost, F.; Safarian, M. Changes in dietary intake during Ramadan in north east of Iran population. J. Fasting Health 2013, 1, 19-22.

47. Adlouni, A.; Ghalim, N.; Saïle, R.; Hda, N.; Parra, H.-J.; Benslimane, A. Beneficial effect on serum apo AI, apo B and Lp AI levels of Ramadan fasting. Clin. Chim. Acta 1998, 271, 179-189. [CrossRef]

48. Hozoori, M.; Kohandani, A.; Mohammadi Veldani, A.; Mirizadeh, M. Nutrient intake during Ramadan in fasting people referring to health centers in Qom, Iran. Health Spiritual. Med. Ethics 2017, 4, 9-11.

49. Husain, R.; Duncan, M.; Cheah, S.; $\mathrm{Ch}^{\prime} \mathrm{Ng}$, S. Effects of fasting in Ramadan on tropical Asiatic Moslems. Br. J. Nutr. 1987, 58, 41-48. [CrossRef]

50. Fakhrzadeh, H.; Lariiani, B.; Sanjari, M.; Baradar-Jalili, R.; Amini, M. Effect of Ramadan fasting on clinical and biochemical parameters in healthy adults. Ann. Saudi Med. 2003, 23, 223-226. [CrossRef]

51. López-Bueno, M.; González-Jiménez, E.; Navarro-Prado, S.; Montero-Alonso, M.A.; Schmidt-RioValle, J. Influence of age and religious fasting on the body composition of Muslim women living in a westernized context. Nutr. Hosp. 2015, 31, 1067-1073. 
52. Norouzy, A.; Salehi, M.; Philippou, E.; Arabi, H.; Shiva, F.; Mehrnoosh, S.; Mohajeri, S.M.; Mohajeri, S.A.; Motaghedi Larijani, A.; Nematy, M. Effect of fasting in Ramadan on body composition and nutritional intake: A prospective study. J Hum Nutr Diet 2013, 26 Suppl 1, 97-104. [CrossRef]

53. Sezen, Y.; Altiparmak, I.H.; Erkus, M.E.; Kocarslan, A.; Kaya, Z.; Gunebakmaz, O.; Demirbag, R. Effects of Ramadan fasting on body composition and arterial stiffness. J. Pak. Med. Assoc. 2016, 66, 1522-1527.

54. Shruthi, B.; Abrar, H.; Reddy, B. The effect of Ramadan fasting on the body composition, blood pressure, heart rate of healthy young adults. Int. J. Recent Trends Sci. Technol. 2013, 8, 31-35.

55. Syam, A.F.; Sobur, C.S.; Abdullah, M.; Makmun, D. Ramadan fasting decreases body fat but not protein mass. Int. J. Endocrinol. Metab. 2016, 14, e29687.

56. Nomani, M.; Hallak, M.; Siddiqui, I. Effects of Ramadan fasting on plasma uric acid and body weight in healthy men. J. Am. Diet. Assoc. 1990, 90, 1435-1436. [PubMed]

57. Nachvak, S.M.; Pasdar, Y.; Pirsaheb, S.; Darbandi, M.; Niazi, P.; Mostafai, R.; Speakman, J.R. Effects of Ramadan on food intake, glucose homeostasis, lipid profiles and body composition composition. Eur. J. Clin. Nutr. 2019, 73, 594-600. [CrossRef]

58. Harder-Lauridsen, N.M.; Rosenberg, A.; Benatti, F.B.; Damm, J.A.; Thomsen, C.; Mortensen, E.L.; Pedersen, B.K.; Krogh-Madsen, R. Ramadan model of intermittent fasting for $28 \mathrm{~d}$ had no major effect on body composition, glucose metabolism, or cognitive functions in healthy lean men. Nutrition 2017, 37, 92-103. [CrossRef]

59. Ramadan, J. Does fasting during Ramadan alter body composition, blood constituents and physical performance? Med. Princ. Pr. 2002, 11 (Suppl 2), 41-46. [CrossRef]

60. Racinais, S.; Périard, J.; Li, C.; Grantham, J. Activity patterns, body composition and muscle function during Ramadan in a Middle-East Muslim country. Int. J. Sports Med. 2012, 33, 641-646. [CrossRef]

61. Finch, G.M.; Day, J.E.; Welch, D.A.; Rogers, P.J. Appetite changes under free-living conditions during Ramadan fasting. Appetite 1998, 31, 159-170. [CrossRef]

62. Mazidi, M.; Karimi, E.; Rezaee, P.; Nematy, M.; Salehi, M. The effects of Ramadan fasting on body composition. Shiraz E Med. J. 1973, 15, e19733. [CrossRef]

63. Al-Numair, K. Body weight and some biochemical changes associated with Ramadan fasting in healthy Saudi men. J. Med. Sci. 2006, 6, 112-116.

64. Shehab, A.; Abdulle, A.; El Issa, A.; Al Suwaidi, J.; Nagelkerke, N. Favorable changes in lipid profile: The effects of fasting after Ramadan. PLoS ONE 2012, 7, e47615. [CrossRef] [PubMed]

65. Jahrami, H.A.; Alsibai, J.; Clark, C.C.; Mo'ez Al-Islam, E.F. A systematic review, meta-analysis, and meta-regression of the impact of diurnal intermittent fasting during Ramadan on body weight in healthy subjects aged 16 years and above. Eur. J. Nutr. 2020, 59, 2291-2316. [CrossRef] [PubMed]

66. Fernando, H.A.; Zibellini, J.; Harris, R.A.; Seimon, R.V.; Sainsbury, A. Effect of Ramadan fasting on weight and body composition in healthy non-athlete adults: A systematic review and meta-analysis. Nutrients 2019, 11, 478. [CrossRef] [PubMed]

67. Hajek, P.; Myers, K.; Dhanji, A.-R.; West, O.; McRobbie, H. Weight change during and after Ramadan fasting. J. Public Health 2011, 34, 377-381. [CrossRef]

68. Sadeghirad, B.; Motaghipisheh, S.; Kolahdooz, F.; Zahedi, M.J.; Haghdoost, A.A. Islamic fasting and weight loss: A systematic review and meta-analysis. Public Health Nutr. 2014, 17, 396-406. [CrossRef]

69. Kocaaga, T.; Tamer, K.; Karli, U.; Yarar, H. Effects of Ramadan fasting on physical activity level and body composition in young males. Int. J. Appl. Exerc. Phy. 2019, 8, 2322-3537.

70. Amiri, F.; Azimi Nezhad, M.; Alinezhad-Namaghi, M.; Jarahi, L.; Nematy, M.; Norouzy, A. Effects of Ramadan fasting on inflammatory biomarkers and body composition in healthy subjects. J. Nutr. Fasting Health 2016, 4, 136-139.

71. Al-barha, N.S.; Aljaloud, K.S. The effect of Ramadan fasting on body composition and metabolic syndrome in apparently healthy men. Am. J. Men's Health 2019, 13, 1557988318816925. [CrossRef]

72. Khaled, T.; Ahmed, C.; Zohra, G.; Choumous, K.; Zouheir, S.; Mounir, Z.K.; Ahmed, H. Physical activity during Ramadan fasting: Effects on body composition, hematological and biochemical parameters. Iosr J. Pharm. 2012, 2, 33-41. [CrossRef]

73. Trabelsi, K.; El Abed, K.; Stannard, S.R.; Jammoussi, K.; Zeghal, K.M.; Hakim, A. Effects of fed-versus fasted-state aerobic training during Ramadan on body composition and some metabolic parameters in physically active men. Int. J. Sport Nutr. Exerc. Metab. 2012, 22, 11-18. [CrossRef] 
74. Haghdoost, A.; Poorranjbar, M. The interaction between physical activity and fasting on the serum lipid profile during Ramadan. Singap. Med. J. 2009, 50, 897-901.

75. Yucel, A.; Degirmenci, B.; Acar, M.; Albayrak, R.; Haktanir, A. The effect of fasting month of Ramadan on the abdominal fat distribution: Assessment by computed tomography. Tohoku J. Exp. Med. 2004, 204, 179-187. [CrossRef] [PubMed]

76. Khattak, M.M.A.K.; Bakar, I.A.; Yeim, L. Does religious fasting increase fat free mass (FFM) and reduce abdominal obesity? Nutr. Food Sci. 2012, 42, 87-96. [CrossRef]

77. Khan, A.; Khattak, M. Islamic fasting: An effective strategy for prevention and control of obesity. Pak. J. Nutr. 2002, 1, 185-187.

78. Rohin, M.A.; Rozano, N.; Abd Hadi, N.; Mat Nor, M.N.; Abdullah, S.; Dandinasivara Venkateshaiah, M. Anthropometry and body composition status during Ramadan among higher institution learning centre staffs with different body weight status. Sci. World J. 2013, 2013, 308041. [CrossRef]

79. Ünalacak, M.; Kara, I.H.; Baltaci, D.; Erdem, Ö.; Bucaktepe, P.G.E. Effects of Ramadan fasting on biochemical and hematological parameters and cytokines in healthy and obese individuals. Metab. Syndr. Relat. Disord. 2011, 9, 157-161. [CrossRef]

80. Celik, A.; Saricicek, E.; Saricicek, V.; Sahin, E.; Ozdemir, G.; Bozkurt, S.; Okumus, M.; Sucakli, M.H.; Cikim, G.; Coskun, Y. Effect of Ramadan fasting on serum concentration of apelin-13 and new obesity indices in healthy adult men. Med. Sci. Monit. Int. Med. J. Exp. Clin. Res. 2014, 20, 337.

81. Suriani, I.; Shamsuddin, K.; Khalib, A.; Hazizi, A.; Fadlan, M. The effect of Ramadan weight loss on body composition of overweight and obese Muslims in University Putra Malaysia. Int. J. Public Health Clin. Sci. 2015, 2, 61-68.

82. Madkour, M.I.; Obaideen, A.K.; Dalah, E.Z.; Hasan, H.A.; Radwan, H.; Jahrami, H.A.; Hamdy, O.; Mohammad, M.G. Effect of Ramadan diurnal fasting on visceral adiposity and serum adipokines in overweight and obese individuals. Diabetes Res. Clin. Pract. 2019, 153, 166-175.

83. Radhakishun, N.N.E. Childhood Obesity: Medical, Cultural and Psychological Factors. Ph.D. Thesis, Utrecht University, Utrecht, The Netherlands, 2014.

84. Salehi, M.; Neghab, M. Effects of fasting and a medium calorie balanced diet during the holy month Ramadan on weight, BMI and some blood parameters of overweight males. Pak. J. Biol. Sci. 2007, 10, 968-971. [CrossRef]

85. Ganjali, N.; Mozaffari-Khosravi, H.; Afkhami Ardakani, M.; Shahraki, M.; Fallahzadeh, H. Effect of islamic fasting on glucose, lipid profiles and Body Mass Index, adiponectin and leptin in obese individuals. J. Nutr. Fasting Health 2016, 4, 57-63.

86. Ongsara, S.; Boonpol, S.; Prompalad, N.; Jeenduang, N. The Effect of Ramadan fasting on biochemical parameters in healthy Thai subjects. J. Clin. Diagn Res. 2017, 11, BC14-BC18. [CrossRef] [PubMed]

87. Larijani, B.; Zahedi, F.; Sanjari, M.; Amini, M.; Jalili, R.; Adibi, H.; Vassigh, A. The effect of Ramadan fasting on fasting serum glucose in healthy adults. Med. J. Malays. 2003, 58, 678-680.

88. Shariatpanahi, Z.V.; Shariatpanahi, M.V.; Shahbazi, S.; Hossaini, A.; Abadi, A. Effect of Ramadan fasting on some indices of insulin resistance and components of the metabolic syndrome in healthy male adults. Br. J. Nutr. 2008, 100, 147-151. [CrossRef] [PubMed]

89. Sarraf-Zadegan, N.; Atashi, M.; Naderi, G.A.; Baghai, A.M.; Asgary, S.; Fatehifar, M.R.; Samarian, H.; Zarei, M. The effect of fasting in Ramadan on the values and interrelations between biochemical, coagulation and hematological factors. Ann. Saudi Med. 2000, 20, 377-381. [CrossRef] [PubMed]

90. Ziaee, V.; Razaei, M.; Ahmadinejad, Z.; Shaikh, H.; Yousefi, R.; Yarmohammadi, L.; Bozorgi, F.; Behjati, M.J. The changes of metabolic profile and weight during Ramadan fasting. Singap. Med. J. 2006, 47, 409.

91. Azizi, F.; Rasouli, H. Serum glucose, bilirubin, calcium, phosphorus, protein and albumin concentrations during Ramadan. Med. J. Islamic Repub. Iran. 1987, 1, 38-41.

92. Kiyani, M.M.; Memon, A.R.; Amjad, M.I.; Ameer, M.R.; Sadiq, M.; Mahmood, T. Study of human Biochemical parameters during and after Ramadan. J. Relig. Health 2017, 56, 55-62. [CrossRef]

93. Beltaifa, L.; Bouguerra, R.; Ben Slama, C.; Jabrane, H.; El Khadhi, A.; Rayana, B.; Doghri, T. Food intake, and anthropometrical and biological parameters in adult Tunisians during Ramadan. EMHJ East. Mediterr. Health J. 2002, 8, 603-611. 
94. Radhakishun, N.; Blokhuis, C.; van Vliet, M.; von Rosenstiel, I.; Weijer, O.; Heymans, M.; Beijnen, J.; Brandjes, D.; Diamant, M. Intermittent fasting during Ramadan causes a transient increase in total, LDL, and HDL cholesterols and hs-CRP in ethnic obese adolescents. Eur. J. Pediatrics 2014, 173, 1103-1106. [CrossRef]

95. Roky, R.; Houti, I.; Moussamih, S.; Qotbi, S.; Aadil, N. Physiological and chronobiological changes during Ramadan intermittent fasting. Ann. Nutr. Metab. 2004, 48, 296-303. [CrossRef] [PubMed]

96. Roy, A.S.; Bandyopadhyay, A. Effect of Ramadan intermittent fasting on haematological parameters, lipid profile, and renal markers in young Muslim males of Kolkata, India. Indian J. Physiol Pharm. 2017, 61, 361-367.

97. Mendelson, M.; Michallet, A.S.; Monneret, D.; Perrin, C.; Estève, F.; Lombard, P.; Faure, P.; Lévy, P.; Favre-Juvin, A.; Pépin, J.L. Impact of exercise training without caloric restriction on inflammation, insulin resistance and visceral fat mass in obese adolescents. Pediatric Obes. 2015, 10, 311-319. [CrossRef] [PubMed]

98. Leung, G.K.; Huggins, C.E.; Bonham, M.P. Effect of meal timing on postprandial glucose responses to a low glycemic index meal: A crossover trial in healthy volunteers. Clin. Nutr. 2019, 38, 465-471. [CrossRef]

99. Darzabi, T.; Hejazi, K.; Shahrokhi, H. The effects of Ramadan fasting on metabolic syndrome and body composition in male students. J. Client Cent. Nurs. Care 2019, 5, 239-246.

100. Gnanou, J.V.; Caszo, B.A.; Khalil, K.M.; Abdullah, S.L.; Knight, V.F.; Bidin, M.Z. Effects of Ramadan fasting on glucose homeostasis and adiponectin levels in healthy adult males. J. Diabetes Metab. Disord. 2015, 14, 55. [CrossRef]

101. Mafauzy, M.; Mohammed, W.; Anum, M.; Zulkifli, A.; Ruhani, A. A study of the fasting diabetic patients during the month of Ramadan. Med. J. Malays. 1990, 45, 14-17.

102. Lessan, N.; Hannoun, Z.; Hasan, H.; Barakat, M. Glucose excursions and glycaemic control during Ramadan fasting in diabetic patients: Insights from continuous glucose monitoring (CGM). Diabetes Metab. 2015, 41, 28-36. [CrossRef]

103. Al-Hader, A.F.A.; Abu-Farsakh, N.A.; Khatib, S.Y.; Hasan, Z.A. The effects of Ramadan fasting on certain biochemical parameters in normal subjects and in type II diabetic patients. Ann. Saudi Med. 1994, 14, 139-141. [CrossRef]

104. Yarahmadi, S.; Larijani, B.; Bastanhagh, M.; Pajouhi, M.; Baradar, R.J.; Zahedi, F.; Zendehdel, K.; Akrami, S. Metabolic and clinical effects of Ramadan fasting in patients with type II diabetes. J. Coll. Physicians Surg. Pak. 2003, 13, 329-332.

105. Alabbood, M.H.; Ho, K.W.; Simons, M.R. The effect of Ramadan fasting on glycaemic control in insulin dependent diabetic patients: A literature review. Diabetes Metab. Syndr. 2017, 11, 83-87. [CrossRef] [PubMed]

106. Khatib, F.A.; Shafagoj, Y.A. Metabolic alterations as a result of Ramadan fasting in non-insulin-dependent diabetes mellitus patients in relation to food intake. Saudi Med. J. 2004, 25, 1858-1863. [PubMed]

107. Khaled, B.M.; Bendahmane, M.; Belbraouet, S. Ramadan fasting induces modifications of certain serum components in obese women with type 2 diabetes. Saudi Med. J. 2006, 27, 23. [PubMed]

108. Sari, R.; Balci, M.K.; Akbas, S.H.; Avci, B. The effects of diet, sulfonylurea, and Repaglinide therapy on clinical and metabolic parameters in type 2 diabetic patients during Ramadan. Endocr. Res. 2004, 30, 169-177. [CrossRef] [PubMed]

109. Benaji, B.; Mounib, N.; Roky, R.; Aadil, N.; Houti, I.; Moussamih, S.; Maliki, S.; Gressier, B.; El Ghomari, H. Diabetes and Ramadan: Review of the literature. Diabetes Res. Clin. Pract. 2006, 73, 117-125. [CrossRef]

110. Norouzy, A.; Mohajeri, S.; Shakeri, S.; Yari, F.; Sabery, M.; Philippou, E.; Varasteh, A.; Nematy, M. Effect of Ramadan fasting on glycemic control in patients with Type 2 diabetes. J. Endocrinol. Investig. 2012, 35, 766.

111. Pallayova, M.; Zaghloul,H.B.; Arora, T.; Choudhury, S.M.; Omar, O.M.; Chagoury, O.L.; Taheri, S. Investigating physiological glucose excursions before, during, and after Ramadan in adults without diabetes mellitus. Physiol. Behav. 2017, 179, 110-115. [CrossRef]

112. Hassanein, M.; Rashid, F.; Elsayed, M.; Basheir, A.; Al Saeed, M.; Abdelgadir, E.; AbuelKheir, S.; Khalifa, A.; Al Sayyah, F.; Bachet, F. Assessment of risk of fasting during Ramadan under optimal diabetes care, in high-risk patients with diabetes and coronary heart disease through the use of FreeStyle Libre flash continuous glucose monitor (FSL-CGMS). Diabetes Res. Clin. Pract. 2019, 150, 308-314. [CrossRef] 
113. Salti, I.; Bénard, E.; Detournay, B.; Bianchi-Biscay, M.; Le Brigand, C.; Voinet, C.; Jabbar, A. A population-based study of diabetes and its characteristics during the fasting month of Ramadan in 13 countries: Results of the epidemiology of diabetes and Ramadan 1422/2001 (EPIDIAR) study. Diabetes Care 2004, 27, 2306-2311. [CrossRef]

114. Hassan, A.; Meo, S. Diabetes during Ramadan: Underestimated, under-investigated, needs more attention. Eur. Rev. Med. Pharm. Sci. 2014, 18, 3528-3533.

115. Monnier, L.; El Azrak, A.; Lessan, N.; Rochd, D.; Colette, C.; Bonnet, F. Ramadan and diabetes: What we see, learn and understand from continuous glucose monitoring. Diabetes Metab. 2015, 41, 456-462. [CrossRef] [PubMed]

116. Lessan, N.; Hasan, H.; Barakat, M.T. Ramadan fasting: A study of changes in glucose profiles among patients with diabetes using continuous glucose monitoring. Diabetes Care 2012, 35, e37. [CrossRef] [PubMed]

117. Jabbar, A.; Hassanein, M.; Beshyah, S.A.; Boye, K.S.; Yu, M.; Babineaux, S.M. CREED study: Hypoglycaemia during Ramadan in individuals with Type 2 diabetes mellitus from three continents. Diabetes Res. Clin. Pr. 2017, 132, 19-26. [CrossRef] [PubMed]

118. Malik, U.; Mahmood, N.; Khan, K.A.; Hameed, M.; Randhawa, F.A.; Salman, S.; Riaz, A.; Waheed, K.; Rasheed, A. Glycemic control of type 2 diabetic patients during ramazan fasting. J. Ayub. Med. Coll. Abbottabad 2017, 29, 102-106. [PubMed]

119. Ahmadani, M.; Riaz, M.; Fawwad, A.; Hydrie, M.; Hakeem, R.; Basit, A. Glycaemic trend during Ramadan in fasting diabetic subjects: A study from Pakistan. Pak. J. Biol. Sci. 2008, 11, 2044-2047. [CrossRef]

120. Lamri-Senhadji, M.; El Kebir, B.; Belleville, J.; Bouchenak, M. Assessment of dietary consumption and time-course of changes in serum lipids and lipoproteins before, during and after Ramadan in young Algerian adults. Singap. Med. J. 2009, 50, 288.

121. Haouari-Oukerro, F.; Ben-Attia, M.; Kaâbachi, N.; Haouari, M. Ramadan fasting influences on food intake consumption, sleep schedule, body weight and some plasma parameters in healthy fasting volunteers. Afr. J. Biotechnol. 2013, 12, 3327-3332.

122. Mansi, K.M.S. Study the effects of Ramadan fasting on the serum glucose and lipid profile among healthy Jordanian students. Am. J. Appl Sci 2007, 4, 565-569.

123. Maislos, M.; Khamaysi, N.; Assali, A.; Abou-Rabiah, Y.; Zvili, I.; Shany, S. Marked increase in plasma high-density-lipoprotein cholesterol after prolonged fasting during Ramadan. Am. J. Clin. Nutr. 1993, 57, 640-642. [CrossRef]

124. Zare, A.; Hajhashemi, M.; Hassan, Z.; Zarrin, S.; Pourpak, Z.; Moin, M.; Salarilak, S.; Masudi, S.; Shahabi, S. Effect of Ramadan fasting on serum heat shock protein 70 and serum lipid profile. Singap. Med. J. 2011, 52, 491-495.

125. Akanji, A.; Mojiminiyi, O.; Abdella, N. Beneficial changes in serum apo A-1 and its ratio to apo B and HDL in stable hyperlipidaemic subjects after Ramadan fasting in Kuwait. Eur. J. Clin. Nutr. 2000, 54, 508. [CrossRef] [PubMed]

126. Maislos, M.; Abou-Rabiah, Y.; Zuili, I.; Iordash, S.; Shany, S. Gorging and plasma HDL-cholesterol-The Ramadan model. Eur. J. Clin. Nutr. 1998, 52, 127. [CrossRef] [PubMed]

127. Temizhan, A.; Tandogan, I.; Dönderici, Ö.; Demirbas, B. The effects of Ramadan fasting on blood lipid levels. Am. J. Med. 2000, 109, 341. [CrossRef]

128. Qujeq, D.; Bijani, K.; Kalavi, K.; Mohiti, J.; Aliakbarpour, H. Effects of Ramadan fasting on serum low-density and high-density lipoprotein-cholesterol concentrations. Ann. Saudi Med. 2002, 22, 297-299. [CrossRef] [PubMed]

129. Akaberi, A.; Golshan, A.; Moojdekanloo, M.; Hashemian, M. Does fasting in Ramadan ameliorate Lipid profile? A prospective observational study. Pak. J. Med Sci. 2014, 30, 708.

130. Nematy, M.; Alinezhad-Namaghi, M.; Rashed, M.M.; Mozhdehifard, M.; Sajjadi, S.S.; Akhlaghi, S.; Sabery, M.; Mohajeri, S.A.R.; Shalaey, N.; Moohebati, M. Effects of Ramadan fasting on cardiovascular risk factors: A prospective observational study. Nutr. J. 2012, 11, 69. [CrossRef]

131. Dowood, T. Effects of Ramadan fasting on blood lipids and sugar. Pak. J. Med. Sci. 2004, 20, 308-310.

132. Hosseini, S.R.A.; Hejazi, K. The effects of Ramadan fasting and physical activity on blood hematological-biochemical parameters. Iran. J. Basic Med Sci. 2013, 16, 845.

133. Al Hourani, H.M.; Atoum, M.F.; Akel, S.; Hijjawi, N.; Awawdeh, S. Effects of Ramadan fasting on some haematological and biochemical parameters. Jordan J. Biol Sci 2009, 2, 103-108. 
134. Asgary, S.; Aghaei, F.; Naderi, G.A.; Kelishadi, R.; Gharipour, M.; Azali, S. Effects of Ramadan fasting on lipid peroxidation, serum lipoproteins and fasting blood sugar. Med. J. Islamic World Acad. Sci. 2000, 13, 35-38.

135. Furuncuoglu, Y.; Karaca, E.; Aras, S.; Yönem, A. Metabolic, biochemical and psychiatric alterations in healthy subjects during Ramadan. Pak. J. Nutr. 2007, 6, 209-211.

136. Mahoob, S.; Sattarivand, R.; Nouri, M.; Arefhosseini, S. Effect of Ramadan fasting on serum lipid profiles in normal and hyperlipidemic subjects. Saudi Med. J. 1999, 20,947-950.

137. Saleh, S.A.; Elsharouni, S.A.; Cherian, B.; Mourou, M. Effects of Ramadan fasting on waist circumference, blood pressure, lipid profile, and blood sugar on a sample of healthy Kuwaiti men and women. Malays. J. Nutr. 2005, 11, 143-150.

138. Thannoun, A.M. Effect of fastnig in Ramadan on blood glucose and lipid profile. Mesop. J. Agric. 2010, 38, 11-15. [CrossRef]

139. Marbut, M.M.; Manssor, A.J.; Abdulrahman, M.A. The effect of Ramadan fasting \& Moderate exercise on body weight, serum glucose \& lipid profile in healthy fasting subjects. Med. J. Tikrit 2006, 2, 26-30.

140. Akhtaruzzaman, M.; Hoque, N.; Choudhury, M.; Uddin, M.J.; Parvin, T. Effect of Ramadan fasting on serum lipid profile of Bangladeshi female volunteers. Bangladesh J. Med. Biochem. 2014, 7, 47-51. [CrossRef]

141. Ismail, W.I.; Haron, N. Effect of Ramadan fasting on serum lipid profile among healthy students in UiTM. In Proceedings of the International Conference on Biological, Chemical and Environmental Sciences (BCES-2014), Penang, Malaysia, 14-15 June 2014; pp. 51-53.

142. Pathan, M.; Patil, R. Effect of Ramadan fasting on body weight and lipid profile. Biomed. Pharmacol. J. 2015, 3, 167-170.

143. Shahsavan, F.; Askarizadeh, F.; Namaty, M.; Heravian, J.; Mahmodi, Z.; Rakhshandadi, T.; Sedaghat, M.R. Effect of Ramadan fasting on blood pressure and lipid profiles. J. Nutr. Fasting Health 2015, 3, 126-131.

144. Khan, N.; Rasheed, A.; Ahmed, H.; Aslam, F.; Kanwal, F. Effect of Ramadan fasting on glucose level, lipid profile, $\mathrm{HbA1c}$ and uric acid among medical students in Karachi, Pakistan. Emhj-East. Mediterr. Health J. 2017, 23, 274-279.

145. Indra, M.R.; Satuman, S.; Widodo, E.; Tinny, E.; Endang, S.; Sudiarto, S.; Soemardini, S. Study of some biochemical parameters in young men as effected by Ramadan Fasting. Yarsi Med. J. 2007, 15. [CrossRef]

146. Patsch, J.R.; Karlin, J.B.; Scott, L.W.; Smith, L.C.; Gotto, A.M. Inverse relationship between blood levels of high density lipoprotein subfraction 2 and magnitude of postprandial lipemia. Proc. Natl. Acad. Sci. USA 1983, 80, 1449-1453. [CrossRef] [PubMed]

147. Afrasiabi, A.; Hassanzadeh, S.; Sattarivand, R.; Nouri, M.; Mahbood, S. Effects of low fat and low calorie diet on plasma lipid levels in the fasting month of Ramadan. Saudi Med. J. 2003, 24, 184-188. [PubMed]

148. Azizi, F. Islamic fasting and health. Ann. Nutr. Metab. 2010, 56, 273-282. [CrossRef] [PubMed]

149. Gumaa, K.; Mustafa, K.; Mahmoud, N.; Gader, A. The effects of fasting in Ramadan: 1. Seram uric acid and lipid concentrations. Br. J. Nutr. 1978, 40, 573-581. [CrossRef]

150. Fedail, S.S.; Murphy, D.; Salih, S.; Bolton, C.; Harvey, R. Changes in certain blood constituents during Ramadan. Am. J. Clin. Nutr. 1982, 36, 350-353. [CrossRef]

151. Shoukry, M. Effect of fasting in Ramadan on plasma lipoproteins and apoproteins. Saudi Med J. 1986, 7 , 561-565.

152. Hallak, M.H.; Nomani, M.Z.A. Body weight loss and changes in blood lipid levels in normal men on hypocaloric diets during Ramadan fasting. Am. J. Clin. Nutr. 1988, 48, 1197-1210. [CrossRef]

153. Albrink, M.J.; Ullrich, I.H. Interaction of dietary sucrose and fiber on serum lipids in healthy young men fed high carbohydrate diets. Am. J. Clin. Nutr. 1986, 43, 419-428. [CrossRef]

154. Nagra, S.; Rahman, Z.; Javaria, M.; Qadri, A.J. Study of some biochemical parameters in young women as affected by Ramadan fasting. Int. J. Ramadan Fasting Res. 1998, 2, 1-5.

155. Kul, S.; Savaş, E.; Öztürk, Z.A.; Karadağ, G. Does Ramadan fasting alter body weight and blood lipids and fasting blood glucose in a healthy population? A meta-analysis. J. Relig. Health 2014, 53, 929-942. [CrossRef]

156. Mazidi, M.; Rezaie, P.; Karimi, E.; Salehi, M.; Nematy, M. Effects of Ramadan fasting on lipid profile: A narrative review. J. Nutr. Fasting Health 2014, 2, 57-61.

157. Mazidi, M.; Rezaie, P.; Chaudhri, O.; Karimi, E.; Nematy, M. The effect of Ramadan fasting on cardiometabolic risk factors and anthropometrics parameters: A systematic review. Pak. J. Med. Sci. 2015, 31, 1250-1255. [CrossRef] [PubMed] 
158. Yousefi, B.; Faghfoori, Z.; Samadi, N.; Karami, H.; Ahmadi, Y.; Badalzadeh, R.; Shafiei-Irannejad, V.; Majidinia, M.; Ghavimi, H.; Jabbarpour, M. The effects of Ramadan fasting on endothelial function in patients with cardiovascular diseases. Eur. J. Clin. Nutr. 2014, 68, 835-839. [CrossRef] [PubMed]

159. Kacimi, S.; Ref'at, A.; Fararjeh, M.A.; Bustanji, Y.K.; Mohammad, M.K.; Salem, M.L. Intermittent fasting during Ramadan attenuates proinflammatory cytokines and immune cells in healthy subjects. Nutr. Res. 2012, 32, 947-955.

160. Askari, V.; Alavinezhad, A.; Boskabady, M.H. The impact of "Ramadan fasting period" on total and differential white blood cells, haematological indices, inflammatory biomarker, respiratory symptoms and pulmonary function tests of healthy and asthmatic patients. Allergol. Et Immunopathol. 2016, 44, 359-367. [CrossRef]

161. Rahbar, A.R.; Safavi, E.; Rooholamini, M.; Jaafari, F.; Darvishi, S.; Rahbar, A. Effects of intermittent fasting during Ramadan on insulin-like growth factor-1, interleukin 2, and lipid profile in healthy Muslims. Int. J. Prev. Med. 2019, 10. [CrossRef]

162. Asadi, H.; Abolfathi, A.A.; Badalzadeh, R.; Majidinia, M.; Yaghoubi, A.; Asadi, M.; Yousefi, B. Effects of ramadan fasting on serum amyloid A and protein carbonyl group levels in patients with cardiovascular diseases. J. Cardiovasc. Thorac. Res. 2015, 7, 55. [CrossRef]

163. Mushtaq, R.; Akram, A.; Mushtaq, R.; Khwaja, S.; Ahmed, S. The role of inflammatory markers following Ramadan Fasting. Pak. J. Med. Sci. 2019, 35, 77. [CrossRef]

164. Yakoob, M.Y. Fasting during Ramadan and obesity. J. Pak. Med Assoc. 2011, 61, 303.

165. Madkour, M.I.; El-Serafi, A.T.; Jahrami, H.A.; Sherif, N.M.; Hassan, R.E.; Awadallah, S. Ramadan diurnal intermittent fasting modulates SOD2, TFAM, Nrf2, and sirtuins (SIRT1, SIRT3) gene expressions in subjects with overweight and obesity. Diabetes Res. Clin. Pract. 2019, 155, 107801. [CrossRef]

166. Kassab, S.; Abdul-Ghaffar, T.; Nagalla, D.S.; Sachdeva, U.; Nayar, U. Serum leptin and insulin levels during chronic diurnal fasting. Asia Pac. J. Clin. Nutr. 2003, 12, 483-487. [PubMed]

167. Alzoghaibi, M.A.; Pandi-Perumal, S.R.; Sharif, M.M.; BaHammam, A.S. Diurnal intermittent fasting during Ramadan: The effects on leptin and ghrelin levels. PLoS ONE 2014, 9, e92214. [CrossRef] [PubMed]

168. Verdich, C.; Toubro, S.; Buemann, B.; Holst, J.J.; Bülow, J.; Simonsen, L.; Søndergaard, S.B.; Christensen, N.J.; Astrup, A. Leptin levels are associated with fat oxidation and dietary-induced weight loss in obesity. Obes. Res. 2001, 9, 452-461. [CrossRef] [PubMed]

169. Marbut, M.M.; Al-Najjar, H.A.-D.S.; Mustafa, A. Effect of Ramadan fasting on some physiological parameters. Med. J. Tikrit 2005, 2, 6-8.

170. Patterson, R.E.; Sears, D.D. Metabolic effects of intermittent fasting. Annu. Rev. Nutr. 2017, 37, 371-393. [CrossRef]

(C) 2020 by the authors. Licensee MDPI, Basel, Switzerland. This article is an open access article distributed under the terms and conditions of the Creative Commons Attribution (CC BY) license (http://creativecommons.org/licenses/by/4.0/). 